\title{
RESOLVING ENVIRONMENTAL ISSUES IN ENERGY DEVELOPMENT: ROLES FOR THE DEPARTMENT OF ENERGY AND ITS FIELD OFFICES
}

PREPARED FOR THE U.S. DEPARTMENT OF ENERGY

PHYLIS L. ELLICKSON, EDWARD W. MERROW

\author{
R-2335-DOE \\ JANUARY 1979
}

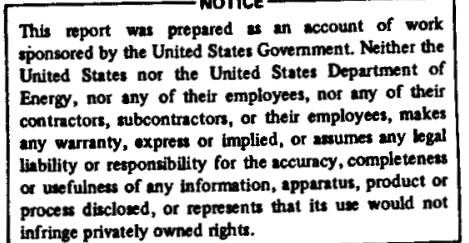

infringe privately owned rights. 


\section{DISCLAIMER}

This report was prepared as an account of work sponsored by an agency of the United States Government. Neither the United States Government nor any agency Thereof, nor any of their employees, makes any warranty, express or implied, or assumes any legal liability or responsibility for the accuracy, completeness, or usefulness of any information, apparatus, product, or process disclosed, or represents that its use would not infringe privately owned rights. Reference herein to any specific commercial product, process, or service by trade name, trademark, manufacturer, or otherwise does not necessarily constitute or imply its endorsement, recommendation, or favoring by the United States Government or any agency thereof. The views and opinions of authors expressed herein do not necessarily state or reflect those of the United States Government or any agency thereof. 


\section{DISCLAIMER}

Portions of this document may be illegible in electronic image products. Images are produced from the best available original document. 


\section{PREFACE}

This report summarizes two Rand studies of the government role in resolving environmental issues arising from the implementation of energy programs. The research was undertaken in 1976-1977 as part of a policy research program sponsored by the Energy Research and Development Administration (now incorporated in the Department of Energy). The first project analyzed two geothermal programs in California: the steam resource development at The Geysers (Lake and Sonoma counties) in northern California, and the wet brine development in the Imperial Valley in southern California. The second project investigated environmental conflicts over oil shale development in Utah and Colorado.

In integrating the findings from the two studies, this report expands the data base and therefore the generalizability of the conclusions reported in a companion report, Phyllis L. Ellickson, with Saundra Brewer and Kathleen Knight, Balancing Energy and the Environment: The Case of Geothermal Development, R-2274-DOE. It identifies common features of an effective conflict resolution process and suggests alternatives for effective federal participation. The report should be useful to policymakers concerned with energy programs in varying locales. 


\section{SUMMARY}

Governmental decisionmakers are increasingly concerned about reconciling energy and environmental goals. This study asks what the Department of Energy (DOE) might do to resolve environmental conflicts that arise during the implementation of energy projects or programs. We define "implementation" as efforts to establish an energy facility at a specific site. The environmental concerns surrounding implementation serve as touchstones of the relevance and feasibility of national energy policies.

We have analyzed geothermal development in California and oil shale development in Colorado and Utah and addressed the following questions:

- By what processes are energy and environmental tradeoffs made?

- In what circumstances can DOE participation in these processes lead to a more satisfactory outcome?

- What options does DOE have for resolving environmental issues and how can it choose the best option?

- How can DOE establish an effective working relationship with both the governmental and private groups affected by the siting and operation of energy projects?

Although based on studies of two energy resources, the following findings reflect our understanding of how environmental-energy tradeoffs are made for other resources as well.

1. Tradeoffs are technology and project specific; they are heavily influenced by local political, economic, and historical conditions.

2. Conflicts rooted in substantive issues are frequently exacerbated by procedural disputes and misinformation about the project's goals, effects, or decisionmaking processes.

3. General tradeoffs outlined in national plans are usually irrelevant to local parties.

4. Knowing the local political, economic, and demographic context makes possible predictions of future conflicts.

5. Conflicts not dealt with immediately tend to become costly adversary disputes; the cost of such conflicts is an incentive to cooperative solutions.

6. Factors that affect cooperative solutions include face to face communication and participation of the parties in the solution process.

7. Because the process of resolving environmental conflicts changes over time, the federal government needs to maintain a continuing local presence to participate effectively in energy development.

The government's most effective role in resolving environmental conflicts and uncertainties is to improve communications among the concerned parties. This role requires flexibility and evenhandedness from the government as well as an understanding of the local conditions and a commitment to appropriate local solutions. Involving local sources at every stage of the environmental impact analysis will 
reduce the probability of conflicts and make those that do arise more easily resolvable.

Federal agencies need to address the following issues when deciding whether to become involved in resolving an environmental conflict:

- Do the local parties want governmental participation in the process of resolving a dispute?

- Are the local parties capable of resolving environmental uncertainties without federal assistance?

- Are the local parties capable of resolving environmental conflicts without federal assistance?

- If federal assistance is appropriate, does the federal government have the resources on site to do the job?

In general, the federal government should provide funds, conduct studies, and mediate disputes only when local resources are inadequate. When a DOE presence is appropriate, its activities should be channeled through a regional office or some other on-site organizational structure.

Many of the criteria for effective governmental participation in resolving environmental conflicts require detailed knowledge of the local conditions. For this reason, DOE field offices provide the most logical tool for creating and maintaining a credible local presence. 


\section{ACKNOWLEDGMENTS}

We owe a considerable debt to the many people who helped carry out the research summarized in this report. The contributions of study team members Saundra Brewer, Kathleen Knight, and Linda Prusoff were indispensable to the success of the research. The comments of Rand reviewers Milbrey McLaughlin and Richard Nehring significantly improved the final draft of the report. In addition, we would like to thank Rand colleagues W. S. Baer and T. K. Glennan, Jr. for their helpful suggestions on earlier drafts.

Finally, this research would not have been possible without the extraordinary cooperation of personnel of the Department of Energy and the Department of the Interior; a host of state and local officials in California, Colorado, and Utah; and representatives of private citizens' groups.

Any remaining errors are the sole responsibility of the authors. 


\section{GLOSSARY}

\begin{tabular}{ll} 
AOSS & Area Oil Shale Supervisor \\
ARB & Air Resources Board \\
BLM & Bureau of Land Management \\
CEQA & California Environmental Quality Act \\
CERCDC & California Energy Resources Conservation and \\
& Development Commission (State Energy Commission) \\
DOE & Department of Energy \\
DOI & Department of the Interior \\
EIR & Environmental Impact Report \\
EIS & Environmental Impact Statement \\
ERDA & Energy Research and Development Administration \\
GRIPS & Geothermal Resource Impact Projection Study \\
IVEP & Imperial Valley Environmental Project \\
KGRA & Known Geothermal Resource Area \\
LLL & Lawrence Livermore Laboratory \\
Mw & Megawatt \\
Mw(e) & Megawatt electric \\
NEPA & National Environmental Policy Act \\
NSAPCD & Northern Sonoma Air Pollution Control District \\
NSF & National Science Foundation \\
OSEAP & Oil Shale Environmental Advisory Panel \\
PG\&E & Pacific Gas \& Electric \\
SAN & San Francisco Operations Office, DOE \\
SDG\&E & San Diego Gas \& Electric \\
USGS & United States Geological Survey \\
& \\
\hline
\end{tabular}




\section{CONTENTS}

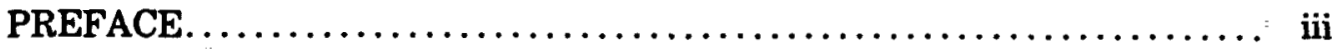

SUMMARY $\ldots \ldots \ldots \ldots \ldots \ldots \ldots \ldots \ldots \ldots \ldots \ldots \ldots \ldots \ldots \ldots \ldots \ldots \ldots \ldots \ldots$

ACKNOWLEDGMENTS $\ldots \ldots \ldots \ldots \ldots \ldots \ldots \ldots \ldots \ldots \ldots \ldots \ldots$ vii

GLOSSARY $\ldots \ldots \ldots \ldots \ldots \ldots \ldots \ldots \ldots \ldots \ldots \ldots \ldots \ldots \ldots \ldots \ldots \ldots \ldots \ldots \ldots \ldots \ldots$

Section

I. INTRODUCTION. .............................. 1

Analyzing Tradeoffs Between Energy and the Environment ..., 1

Research Approach............................ 3

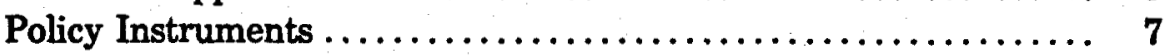

Organization of the Report ....................... 8

II. ENVIRONMENTAL ISSUES IN GEOTHERMAL DEVELOPMENT . 9

Technologies .................................. 9

Environmental Impacts............................. 11

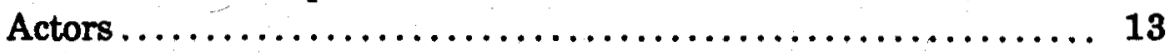

Conflicts at The Geysers $. \ldots \ldots \ldots \ldots \ldots \ldots \ldots \ldots \ldots \ldots \ldots . \ldots \ldots$

Development in the Imperial Valley................... 20

III. ENVIRONMENTAL DISPUTES IN OIL SHALE DEVELOPMENT. . 23

Technologies and Impacts. ....................... 24

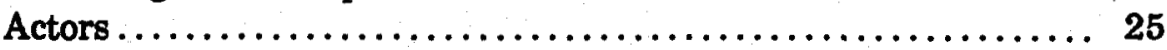

Examples of Conflict and Cooperation ................. 26

Oil Shale and Intergovernmental Disputes............... 29

IV. PRINCIPAL FINDINGS $\ldots \ldots \ldots \ldots \ldots \ldots \ldots \ldots \ldots \ldots \ldots \ldots \ldots, \mathbf{3 1}$

Factors Affecting Environmental/Energy Tradeoffs $\ldots \ldots \ldots \ldots \ldots, 31$

Sources of Opposition $\ldots \ldots \ldots \ldots \ldots \ldots \ldots \ldots \ldots \ldots \ldots \ldots \ldots, 33$

Processes of Environmental Conflict Resolution ............. 36

Conclusion .................................40

V. IMPLICATIONS FOR DOE AND ITS FIELD OFFICES $\ldots \ldots \ldots \ldots \ldots 41$

The Role of Environmental R\&D ...................... 41

Resolving Environmental Conflicts ................... 42

BIBLIOGRAPHY $\ldots \ldots \ldots \ldots \ldots \ldots \ldots \ldots \ldots \ldots \ldots \ldots \ldots \ldots \ldots \ldots \ldots, 49$ 


\section{INTRODUCTION}

Since the passage of the National Environmental Policy Act of 1969 and the oil crisis of 1973-1974, decisionmakers at all levels of government have become increasingly concerned about balancing energy and environmental goals. This study investigates what the Department of Energy's (DOE) role might be in the resolution of environmental issues that arise during the implementation of energy projects. ${ }^{1}$ We have analyzed geothermal development in California and oil shale development in Colorado and Utah and address the following questions:

- What is the nature of the processes through which energy and environmental tradeoffs are made?

- In what circumstances can DOE involvement in these processes lead to more satisfactory outcomes for the parties involved?

- What options are available to DOE for resolving environmental issues? How can DOE determine which option is best?

- How can DOE develop working relationships with governmental and private groups whose interests are affected by the siting and operation of energy projects?

In this study, we define "implementation" as efforts to establish an energy facility at a specific site. Beginning with site or area specific planning for a project or program, implementation is the process through which energy goals are translated into on-site results. Implementation activities may range from resource evaluation or environmental baseline analyses in preparation for development to full scale commercial operation of an energy facility. They may be undertaken by private or governmental bodies or both.

In the remainder of this section, we explain why we focus on environmental issues arising out of the implementation of energy projects, describe our research approach, and outline the policy instruments considered.

\section{ANALYZING TRADEOFFS BETWEEN ENERGY AND THE ENVIRONMENT}

The opportunity to make tradeoffs between energy and environmental goals occurs at several points in DOE's process of making and implementing energy policy. In developing national energy plans, for example, DOE must consider the environmental consequences of alternative energy paths. Its research and development choices may lead to a range of environmentally damaging technologies or a range of effective abatement techniques and its project funding decisions require an assessment of each project's environmental costs. Although each of these choices contributes to the balancing of energy and environmental goals, any national energy policy must ultimately be tested at the level of particular projects in particular

'The need to balance environmental goals and energy development was explicitly recognized in the National Energy Plan of DOE predecessor ERDA. See ERDA 76-1. 
sites. Hence this study focuses on the resolution of conflicts that arise out of the implementation of energy projects or programs.

We chose to focus our research on site-related environmental conflicts that arise during implementation because that is when many federal programs encounter difficulty and the most serious environmental objections arise. Several studies have shown that federal programs often fail to achieve their goals during implementation and that this failure typically stems from an inability to adapt the project to the concerns of those people who must accept its presence in their community. These findings have been duplicated for federal programs in the fields of education, housing, and transportation; ${ }^{2}$ similar difficulties face federal energy projects as well. Certainly, additional questions about a project's environmental consequences emerge during implementation, and old problems take on added intensity as they come closer to affecting people in particular locations. Realization of federal energy plans requires such questions be clarified and the disputes resolved. We have only to recall the nuclear power experience to recognize how effective environmental opponents can be in spurring changes in federal standards, procedures, and R\&D as well as changes in plant design, siting, and operations (Rolph, 1977).

Uncertainty about the federal government's options and capacity to influence outcomes is greater for the implementation phase than for the others. This uncertainty results in part from the difficulty of carrying out national objectives in a federal system. At a minimum, the federal government must obtain local acceptance of a national project or program as a prerequisite for successful implementation; at most, it must rely on local people to carry out its policies. ${ }^{3}$ Because federal policies are always influenced by local priorities and sometimes dominated by locally determined implementation processes, it is in the federal interest to understand existing commonalities and possibilities for influence.

Identifying such commonalities is confounded by the fact that environmental conflicts over specific projects usually involve diverse actors-industry, private citizens, environmental organizations, the courts, and public officials from several government levels. To identify useful roles for a federal agency, one must examine how different environmental problems arise, what factors contribute to their successful resolution, and what leverage the federal government can exert to influence the behavior of these diverse actors.

In asking how the federal government might contribute to the resolution of site-related environmental conflicts, we have sought to understand how energy and environmental tradeoffs are made and to use that understanding to suggest options for federal action. Our analysis of those processes has been guided by the following assumptions: (1) satisfactory tradeoffs between environmental quality and energy development typically have to be made in the political arena rather than in the economic marketplace; (2) tradeoffs where one side has little to gain and the other much to lose or vice versa have almost predetermined outcomes and thus offer little scope for federal influence. Therefore, we have emphasized conflicts where there is a potential for bargaining.

\footnotetext{
2 Berman, McLaughlin, et al. (1974-1977) make this point for education; Cook (1976), Derthick (1970), and Pressman and Wildavsky (1973) for housing; Johnson (1976) for transportation.

"In this report, the word "local" is construed broadly to mean those directly involved in or affected by project implementation and does not necessarily refer to local governments or to those who live near an energy project.
} 
The political nature of conflicts between environmental and energy goals stems from a lack of sufficient incentives for households or firms to bear the costs of environmental degradation. For example, in the absence of regulatory controls, a firm that pollutes the air cannot be sued and forced to pay damages (or reduce its emissions) because no one owns the air and thus no one has standing in the courts. In such cases, market incentives to maximize profits often lead toward environmental degradation. Even where property rights do exist-for example, when several individuals own different sites on a mountain-the sale of one parcel for industrial development does not usually compensate the other landholders for the spillover effects of noise or unsightly construction. Because the market does not provide incentives for internalizing such costs, it does not produce a socially optimal allocation of resources between energy production and environmental protection. If environmental quality is to be provided in such cases, it must be through political means-administrative, individual, or legislative action prodded by the efforts of environmentally concerned individuals or groups.

Resolution of environmental and energy conflicts is largely dictated by economics when the costs to energy producers of ameliorating damage are low and those to environmentalists of bearing the damage are high. In that case, the producer will probably bow to the environmentalists' demands rather than incur the heavier costs of delay or outright obstruction of the facility. In the reverse case, the enyironmentalists are unlikely to press the issue. But when the costs are approximately symmetrical (both parties feel they will suffer considerable harm if the other wins the fight), there is a potential for bargaining.

We argue that asymmetrical conflicts offer few opportunities for federal influence: The outcome is usually determined by the sharp imbalance in costs experienced by the opposing parties and is not amenable to bargaining or negotiation." We concentrate on conflicts that fall into the symmetrical category, which covers a wide variety of conflict situations.

\section{RESEARCH APPROACH}

\section{Geographical and Resource Focus}

We chose to analyze the problems associated with geothermal and oil shale development because they offer the following contrasts: (1) in the actual or potential severity of environmental impacts, (2) in the maturity of the technologies associated with each resource, and (3) in the state and local political cultures where development is taking place.

Producing electricity from geothermal steam or hot brines is unlikely to generate great changes in the resource area's labor force, industrial structure, or land contours. In contrast, large scale oil development may require substantial mining and will introduce one major industry and probably several secondary ones into the rural and often pristine environment of western Colorado and northeastern Utah. Comparing environmental opposition to development of these two resources allowed us to study contrasting scenarios of conflict emergence and resolution: one

\footnotetext{
- However, one option open to the federal government is that of changing the costs through research and development leading to less expensive or more effective abatement techniques.
} 
where the potential effects are limited compared with those of other energy sources and one where they are fairly severe. ${ }^{5}$ We could then ask whether global measures of environmental damage are useful predictors of the emergence of environmental opposition to specific projects.

Developing geothermal and oil shale resources will entail using technologies at different levels of development. To produce electricity from geothermal steam involves a known commercial technology, but the technology appropriate for producing electricity from hot geothermal brines has not been used commercially in the United States. Oil shale technologies vary from well-developed (although not commercially applied) surface retorting processes to true in situ techniques still in the development stage. These situations allow us to explore how the technological state of the art affects the extent to which environmental issues are perceived.

Oil shale development is concentrated in Colorado and Utah and geothermal development activities are currently most heavily carried on in California. To maximize the probability of being able to observe actual processes of issue creation and conflict resolution, we concentrated on these three states and on those counties where resource development is or is likely to be most active-Sonoma, Lake, and Imperial Counties in California; Garfield and Rio Blanco in Colorado; and Uinta County in Utah. The political cultures of these three states (and the counties) differ sharply: Both Colorado and California have heterogeneous populations, a tradition of environmental awareness, and a recent history of turnover in the party controlling the executive and the legislature. These characteristics increase the political stakes associated with balancing environmental and energy goals and offer'more fertile ground for conflict than in Utah, where the heavily Mormon population is fairly homogeneous in political outlook and environmental concerns have failed to capture substantial public or official attention.

All three states are sensitive to federal encroachment on their prerogatives. Colorado and Utah politicians are particularly vocal in assailing federal impingement on states' rights, but California has more developed political institutions and a stronger tradition of local government autonomy. Because implementation in a federal system is heavily influenced by state and local powers and priorities, these contrasts expand our ability to take into account important local realities (such as the capabilities and motivations of local regulatory agencies) that may significantly affect the progress of federal energy policy.

Finally, the resources chusen offer some opportunity for observing ERDA's (and later DOE's) involvement in project implementation. ${ }^{8}$ In association with the funding of a test facility in California's Imperial Valley, ERDA conducted a major environmental baseline study that provides an example of site-related project implementation. At The Geysers, where there has been commercial production of electricity from geothermal steam for many years, ERDA and its successor have expressed considerable interest in facilitating the resolution of environmental and related issues that slow development. Although the Department of the Interior (DOI) has been the federal "lead" agency in oil shale development, ERDA was the

\footnotetext{
See Secs. II and III for more detailed descriptions of the actual and potential effects associated with developing both resources.

- This research was conducted before the DOE absorbed ERDA. Because DOE's jurisdiction includes responsibility for ERDA's former activities and facilities, the findings reported here are equally relevant to the new department. Throughout the report, we refer to ERDA when discussing past agency activities and to DOE when discussing future options.
} 
lead agency for oil shale commercialization efforts, and DOE will undoubtedly be increasingly involved in all aspects of oil shale development over time.

\section{Methods of Analysis}

In examining the development process over the past 15 years, we looked for issues that arose as either unresolved questions about environmental impacts or conflicts over likely or actual impacts. We then traced their development and resolution over time, asking the following questions:

- What environmental issues are associated with development of each resource? To what degree does environmental uncertainty or conflict impede development?

- What is the regulatory and political context within which environmental issues are resolved?

When have environmental issues arisen as disputes? Why? Who are the principal public and private actors concerned with environmental issues? How has involvement occurred? Who has been left out or failed to participate, and with what effect?

Through what mechanisms (e.g., the courts, regulatory bodies, informal contacts) have environmental issues been raised? What are the outcomes of the resolution process?

- What has been the nature of the federal involvement in resolving environmental issues associated with geothermal and oil shale development? What can we learn from past federal experience?

We have used a modified case study approach in which the unit of analysis is the individual environmental issue, broadened to incorporate an appropriately comprehensive consideration of the historical, political, economic, and legal context. The data base is composed of a series of case studies involving two different energy resources, six counties, and three western states.

For our case studies of past environmental conflicts, we have identified environmentalists by their past behavior: We have defined an environmentalist as someone who has taken action to delay, modify, or end an energy project on the grounds that the project's negative effect on the natural or social environment outweighs its benefits. Such action can range from writing a letter, donating funds, or distributing information to lobbying before legislative bodies or becoming a party to a lawsuit. As we note in Section IV, anticipating environmental problems early in the life of a project can mitigate the mobilization of latent opposition. Such anticipation requires a prospective definition of an environmentalist as someone who is likely to be harmed by changes in the social and natural environment resulting from the project. Both the retrospective and prospective definitions are important analytic constructs: The former allows the policymaker to draw useful conclusions from the past; the latter allows him to apply those lessons to future situations.

To derive lessons from past experience we have concentrated, where feasible, on instances of federal participation in resource development. These cases run the gamut from limited federal participation (geothermal development at The Geysers) to substantial involvement (oil shale leasing). This variation has allowed us to explore how different levels of federal activity affect the emergence, development, and outcome of environmental issues. 
A few of the environmental conflicts examined were unaffected by federal inputs. These conflicts are significant not only because private development affects the realization of national energy policy goals but also because they shed light on the need for federal involvement.

The ability to generalize the results reported here is limited because we examined only two resources in three areas. The primary goal of the analysis, however, is to provide insight into the functioning of environmental conflicts and ways that they might be resolved rather than to provide a set of "how to" guidelines for federal involvement.

\section{Examining Outcomes}

Because we are comparing projects at very different stages of development, gauging project outcomes simply on the basis of the extent of environmental protection versus the extent of energy production would be inappropriate. Furthermore, implementation often yields a series of results rather than a single and final outcome. Therefore we have concentrated on the process surrounding environmental conflict resolution during project implementation and the outcomes of that process. Our major criterion for successful conflict resolution is the extent to which the concerned parties are satisfied with both the fairness of the process and any resolutions achieved.

We have chosen this approach because it is becoming increasingly apparent that the most effective way to achieve energy development goals is through acknowledging and accommodating the concerns of all the interested parties. Such accommodation does not mean that each interest gets precisely what it wanted; it does mean that the involved parties feel they have been included in the process and that their concerns have been seriously considered.

Thus, the satisfaction criterion has both substantive and procedural components. Substantively it means that the outcome is considered fair-e.g., that the involved parties feel the project's social benefits exceed or equal the social costs and that these benefits and costs are equitably distributed. Procedurally, it means that those who want a voice in the decisionmaking process can be heard. When these conditions are not met, the resolution is usually so fragile that it quickly breaks down and the conflict reemerges in a more hostile and costly arena. The parties have solidified their positions and are less favorably disposed to compromise solutions. And if development has proceeded past the design stage, the costs of delay, obstruction, or retrofitting are greater.

The satisfaction criterion implies no normative judgment other than the value of efficiency. The realities of the federal system, which generally limit the ability of the federal government to control implementation processes, make accommodation to nonfederal actors necessary for the efficient resolution of most environmental disputes involving the federal government.

Environmental disputes are frequently complicated by uncertainty about what the environmental impacts and costs of control will be. In some cases the reduction of uncertainty through more research or more credible presentation of research results becomes a focus of substantive disputes. The reduction of uncertainty may either exacerbate or mitigate substantive disputes depending upon how the expected costs and benefits of the project are affected. Therefore, we will consider the 
amount of uncertainty about impacts and the costs of their control along with substantive issues as a source of conflict.

\section{POLICY INSTRUMENTS}

In assessing the implications of our findings for DOE's role in resolving environmental issues, we considered the six following options: ${ }^{7}$

- No role is self-defining.

- Disseminating information involves making environmental data at DOE's disposal available to parties interested in site-related environmental questions. This option should be distinguished from the task of data transfer associated with site-related projects conducted by DOE. Effective data transfer from such projects is predicated upon considerable local involvement in project planning and implementation; effective information dissemination does not depend on previous involvement of the users. Because communicating project information and expertise to local decisionmakers is an integral part of site-related activities, we include data transfer in the "conducting studies" option."

- Providing funds includes funding environmental studies (assessments or planning studies not conducted by DOE), supporting local organizations concerned with resolving environmental issues (regulatory agencies, local governments, joint governmental bodies, etc.), or making transfer pay: ments to communities that suffer undue environmental damage.

- Facilitating cooperative endeavors means promoting cooperation and coordination among the many public and private entities actively involved in energy development and environmental protection. It covers a vast range of specific activities: for example, helping an environmental project get off the ground (putting together the interested parties and locating sources of funds and expertise); providing consultants or technical assistance to intergovernmental bodies; conducting or participating in workshops; providing forums within which communication can take place; helping to modify regulatory or administrative processes that increase conflicts between energy and environmental goals. Its defining characteristics are that the federal role is facilitative, rather than directive, and that the specific form of facilitating varies according to the individual problem and actors at issue.

\footnotetext{
There is an important role for DOE in the development of technologies (such as slant drilling or fluidized bed combustion) that are initially designed to alleviate environmental problems associated with energy development. Similarly, DOE's mission includes laboratory studies of the unexpected effects of resource extraction and conversion (such as how various emissions may affect plant and animal life over the longer term). Because industry has few incentives to worry about environmental effects that have not yet been identified, this area is one in which government funds are unlikely to duplicate private efforts. However, neither of these laboratory R\&D options falls within the scope of this study, for neither is closely tied to implementation-site or area specific activity for an energy project. Hence, we have not included them in the above discussion.

- The ERDA-sponsored education program of the Oak Ridge Associated Universities is one example of information dissemination. The data transfer function is illustrated by the Imperial Valley Environmental Project, a site-specific research effort designed to provide inputs to the development and planning decisions of both local governments and industry.
} 
- Conducting studies includes undertaking environmental or planning analyses in conjunction with site-specific resource development (pilots, demonstrations, or private commercial enterprises).

- Mediation entails providing an impartial mediator from DOE who at the very minimum communicates and interprets the positions of both sides to each other, and may also assist in defining the issues, identifying areas of agreement and disagreement, and devising possible compromises. Mediation differs from encouraging cooperative endeavors in that the latter may occur when there is no dispute. Moreover, for mediation to occur when a conflict does exist requires a formal request for assistance, acceptance of the DOE mediator as impartial, and recognition that a formal process of negotiation is underway by all parties to the conflict. Informal attempts to further communication and devise compromise may occur without meeting any of these conditions and thus come under the heading of facilitating cooperative endeavors.

\section{ORGANIZATION OF THE REPORT}

Sections II and III provide background information about geothermal and oil shale: the technologies and environmental impacts associated with each resource, the actors who have played important roles in the development process, the issues that have arisen over the past $\mathbf{1 5}$ years, and the context within which those issues have or have not been resolved.

Section IV contains the principal findings of our examination of environmental conflicts and uncertainties. It sets forth our conclusions about the characteristics of tradeoffs between environmental and energy goals, the sources of opposition, and the processes of environmental conflict resolution.

Section $\mathrm{V}$ discusses the implications of our findings for the federal role in resolving environmental uncertainties and conflicts. It identifies factors that should guide the choice among alternative policy instruments and outlines the organizational implications of the analysis for DOE. 


\section{ENVIRONMENTAL ISSUES IN GEOTHERMAL DEVELOPMENT}

Geothermal energy is derived from the earth's natural heat and stored in hot or molten rock and in the water and steam that fill underground rock pores and fractures. Hydrothermal systems-vapor or liquid-dominated reservoirs-account for all the electricity currently produced from the world's geothermal reserves; California's hydrothermal resource accounts for over 70 percent of the electrical energy potentially recoverable from such reservoirs in the United States (JPL, 1976). The largest geothermal power plant in the world is located at The Geysers dry steam reservoir in northern California; this Known Geothermal Resource Area (KGRA) ${ }^{1}$ overlaps portions of four counties, with most of the development currently taking place in Sonoma and Lake Counties. Electricity has not been produced commercially at any of the liquid-dominated reservoirs in the United States, but southern California's Imperial Valley is one of the most likely candidates. ${ }^{2}$ This section describes the history of geothermal development in the three California counties where it has been most active-Sonoma, Lake, and Imperial. ${ }^{3}$ See Fig. 1.

\section{TECHNOLOGIES}

Converting The Geysers' vapor-dominated resource to electricity is fairly simple. Conventional oil field drilling is used to tap the reservoir, with compressed air substituting for drilling mud after the initial drilling stages. Simple filters remove particulate matter from the well-head steam, which then passes through insulated pipes to the plant and expands through a turbine generator to generate electrical power. The steam is then routed to a direct contact condenser where cooling water mixes with the steam and condenses it. The liquid coolant and condensate are pumped to the cooling tower and most of the condensed water is evaporated. Excess condensate is injected back into the reservoir.

The more complex systems for handling the Imperial Valley's liquid-dominated reservoirs have not yet been proven technically or economically feasible. Because the temperature and salinity of the water vary from one location to another, utilities are considering three different plant designs: flashed steam, binary fluid (or binary flow), and a hybrid of the two. All three systems include reinjecting the brines into nonproducing wells as the waste volume from a full size power plant (50 $\mathrm{Mw}(\mathrm{e})$ or more) exceeds feasible quantities for brine evaporation ponds.

In the flashed steam option, the simplest and least expensive of the three systems, the brines are flashed to a steam vapor, which then passes through a

A KGRA is defined as "an area in which the geology, nearby discoveries, competitive interests, or other indicia would, in the opinion of the Secretary of the Interior, engender a belief in men who are experienced in the subject matter that the prospects for extraction of geothermal steam or associated resources are good enough to warrant expenditures of money for that purpose" (PL 91-581).

${ }^{2}$ Deep drilling has confirmed that there are reservoirs in four of the Imperial Valley's KGRAs; plans for two power plants of approximately $50 \mathrm{Mw}(e)$ have already been announced.

3 See Ellickson (1978) for a more detailed description of geothermal development history in these areas. 


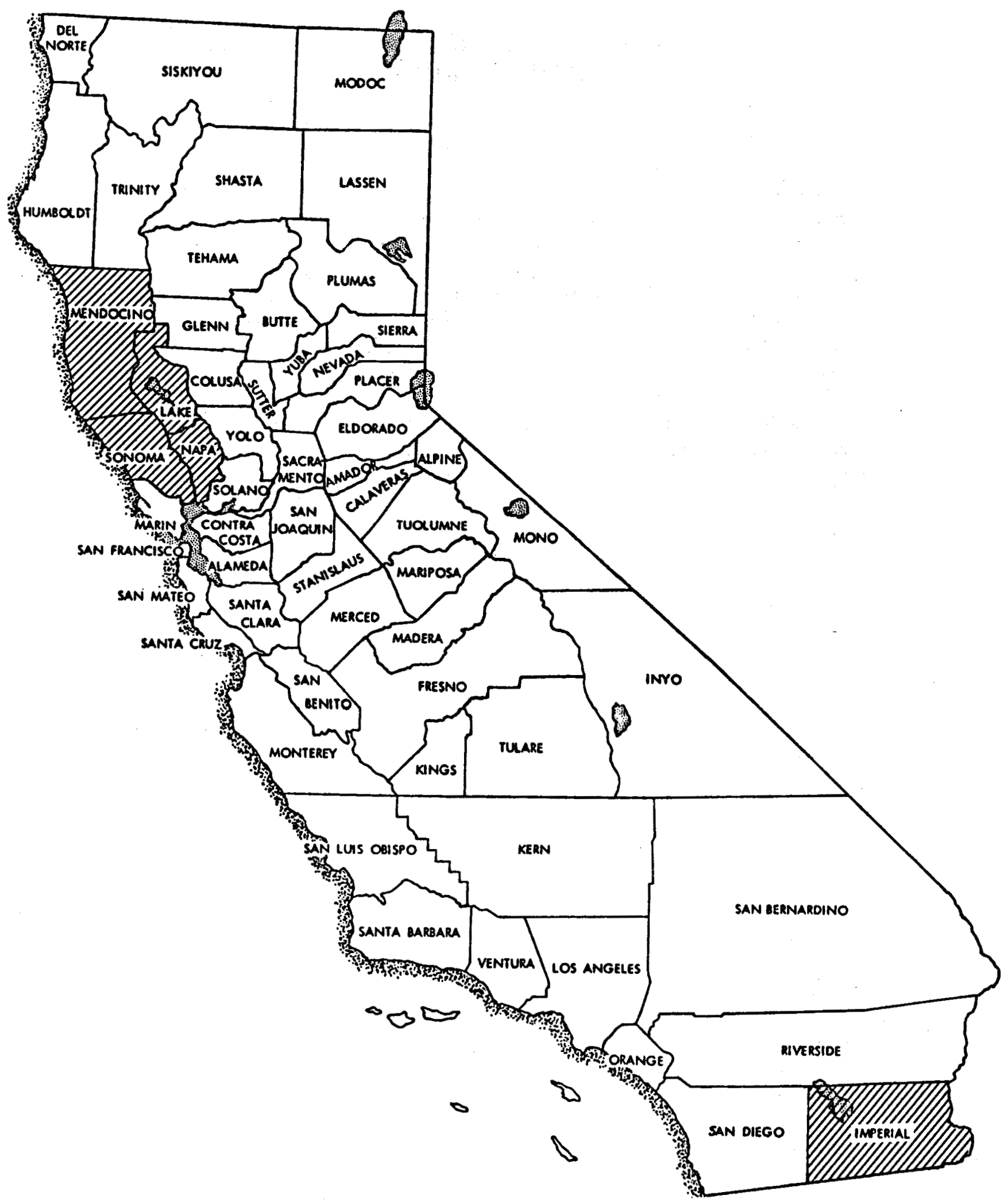

Fig. 1 - Location of Imperial, Lake, Mendocino, Napa, and Sonoma counties 
conventional turbine generator. But if the geothermal fluid is highly saline (as at the valley's Salton Sea reservoirs), solid deposits on the turbine blades and in the liquid flow lines reduce the system's efficiency. In binary flow designs, the brines pass through a series of heat exchangers that transfer the thermal energy to a noncorrosive working fluid (usually freon, isobutane, propane, or isopentane). The vaporized working fluid runs the turbines, the corrosive brines do not come into contact with the turbine or condenser materials, and maintenance and scaling problems are substantially reduced. The hybrid flush-binary system combines flashing brines to steam with the subsequent steam heating of a working fluid in a binary flow system. This process prevents the fouling of heat exchanger tubes that occurs in the simple binary cycle, but it shares the binary system's other disadvantageshigher capital cost and inadequate turbine development.

\section{ENVIRONMENTAL IMPACTS}

At The Geysers, where electricity has been produced from the steam resource since 1960, the environmental consequences of geothermal development are well known. In the Imperial Valley, where no power plants have yet been constructed, effects are less certain. Environmental impacts that have generated public concern at The Geysers include hydrogen sulfide emissions, noise (from drilling), and land disturbance. Those most likely to arise in the Imperial Valley include land subsidence, induced seismicity, scarce water supplies, and water pollution. These contrasts are a result of differences in the technology required for steam and hot brine resources as well as differences in the physical and socioeconomic characteristics of the two areas.

In The Geysers area, the air is quite pure. Hydrogen sulfide emissions from the power plants not only exceed ambient air quality standards, but the odor can easily be detected by local residents. In contrast, some of the projects planned for the Imperial Valley involve reinjection of the cooled brines and noncondensable gases. Because there are also strong odors from feed lots and controlled agricultural burning, hydrogen sulfide emissions from geothermal development are less likely to be noticed by the local residents.

Similarly, degradation of the land by geothermal plants and equipment conflicts sharply with the scenic beauty of the mountains in Sonoma and Lake Counties; the flat lands of the Imperial Valley are valued more for their agricultural use

\footnotetext{
Capital costs are higher because the binary and hybrid systems require larger heat transfer areas to extract thermal energy from the geothermal fluids; turbines that can handle the organic working fluids are not available in the 50 to $100 \mathrm{Mw}(\mathrm{e})$ sizes required.

- Hydrogen sulfide emissions frequently exceed the California ambient air quality standard of .03 parts per million at The Geysers (Tolmasoff, 1976). The problem is not one of toxicity but of odors that annoy those who live downwind. Most of the noise pollution occurs during feld exploration and development, declining to an acceptable range once the field is producing. Finally, each $110 \mathrm{Mw}(e)$ plant requires 15 to 20 wells spaced $1 / 8$ to $1 / 4$ mile apart or approximately one square mile of land. The undisturbed portion of the area where the wells, steam lines and power plants are located may continue to be used for other purposes such as grazing cattle or agriculture. Although each of these impacts appears small in absolute terms, they have generated public complaint and action (e.g., extended public hearings, threats of court suits, and actual court actions). For further details on the environmental impacts of geothermal development, see Ellickson (1978).

- Even if all the Imperial Valley plants use the flashed steam design, ambient air quality standards are not likely to be exceeded until approximately $3000 \mathrm{Mw}(\mathrm{e})$ come on line (Ermak, 1978)-until the capacity is about six times that at The Geysers.
} 
than for their aesthetic appeal. ${ }^{7}$ Nevertheless, Imperial County will probably require developers to minimize the land area occupied by geothermal facilities.

The problems of seismicity and land subsidence, which generate concern in the Imperial Valley, are insignificant in The Geysers area. ${ }^{8}$ In the steep mountains of Lake and Sonoma counties, subsidence that may have occurred naturally is not noticeable. But in the flat Imperial Valley, land subsidence or induced seismicity could disrupt the irrigation and drainage canals on which the agricultural economy depends. Both problems are also more likely to occur in the Imperial Valley because of the greater volume of hot brine that must be withdrawn to produce electricity equivalent to that from a vapor system.

Finally, although waste waters can be disposed of by reinjection in both areas, there is still some uncertainty about the feasibility of reinjecting large volumes of waste brines in the Imperial Valley. 'If reinjection is not feasible, disposing of waste brines will present formidable problems. Furthermore, if reinjection of all the withdrawn geothermal fluid is necessary to avoid subsidence, the condensate would not be available as a cooling water source and other water supplies would be needed. Finding adequate cooling water supplies in the arid valley could constitute a major obstacle to large-scale development of the resource. ${ }^{10}$

Geothermal energy production is often considered a clean process that inflicts little damage on the environment. Certainly, the environmental impacts of electricity production from geothermal resources at The Geysers appear minor on any absolute scale. Hydrogen sulfide emissions are an odor problem, not a safety problem; drilling noise can be mitigated by mufflers and is prohibited during the evening hours; and the land requirements (of approximately one square mile of land for each $110 \mathrm{Mw}(\mathrm{e})$ plant) pale beside those required to generate the same amount of electricity from oil shale or coal. However, these environmental impacts are also geographically confined. Unlike coal or nuclear production, for example, resource extraction and electricity production must occur near the well field. This means there is little freedom to minimize local impacts (such as introducing offensive odors into pristine areas, building plants in scenic locations, competing for scarce water supplies, etc.) by judicious power plant siting.

The localized nature of geothermal energy production also means that its environmental consequences vary from place to place and cannot be ranked on a general scale. Furthermore, the general public's awareness of environmental problems has been largely determined by whether or not actual damage has occurred as a result of geothermal development. And local evaluation of such damage is affected by the degree to which the development complements or conflicts with the area's economy and lifestyle. It is this variation in effects and perceptions that shapes conflicts over geothermal development in California.

\footnotetext{
- Damage to the delicate sand dune area near Glamis and Dunes would provoke environmental concern but these areas are not likely to be developed.

- A study of microearthquakes in The Geysers area after production was under way concluded that the activity was naturally induced. Similarly, geothermally induced subsidence has not been detected at The Geysers.

- Uncertainty about the ability to inject spent brines revolves around plugging of injection lines and injection wells with silica precipitated from the brines as they are cooled.

${ }^{10}$ At The Geysers, the condensate is used as a source of cooling water. In less sensitive areas of the Imperial Valley, it may be possible to withhold the condensate from injection without danger of significant subsidence and thus to use it as a cooling water source. At present, however, there is insufficient evidence to predict the success or failure of this strategy.
} 


\section{ACTORS}

Environmental disputes over geothermal development are distinguished by the dominance of local groups, both private and public, in the conflict resolution process. Local rather than state or national organizations raise the most intense objections to geothermal operations; local regulatory bodies make the critical decisions affecting development. Consequently, the actors and issues vary from one county to another.

\section{Citizen Opposition}

Opposition to geothermal development in California counties ranges from nonexistent to highly vocal and activist. For example, in Imperial County, where there is no actual experience with operating power plants, the citizenry is generally not well informed about geothermal activities and unconcerned about potential effects on the environment. In Lake County, where experience with operating power plants is limited to those units already operating in its neighbor county, the citizenry is considerably more knowledgeable about geothermal activities and divided on their merits. Although two-thirds of Lake County residents are in favor of controlled geothermal development (Vollintine and Weres, 1976a and b), the third of the county that expresses doubts is highly vocal. They have an organization of approximately 1,100 members and a newsletter informing its readers of upcoming hearings and regulatory decisions. They have filed three suits against negative declarations by county agencies. Finally, Sonoma County's residents have not opposed geothermal development. No local organizations have surfaced to protest specific wells or plants nor has Sonoma's Environmental Protection Committee (set up under the California Environmental Quality Act-CEQA) evidenced concern about environmental problems at The Geysers. Environmental conflicts in Sonoma County are generated externally, by Lake County protests over hydrogen sulfide emissions wafting over the border.

Yet the lack of a broad-based state or regional opposition to geothermal development does not mean that the concerns that are expressed are ineffectual. It does mean that effective opposition to geothermal development has typically required a local base. In Napa County, for example, local wine growers succeeded in putting through a moratorium on geothermal development until the county came up with environmental guidelines that greatly constrain development. In Lake County, lengthy EIR hearings as well as court suits have delayed drilling for several months.

Local efforts to protect the environment in these areas are in part attributable to the CEQA, which requires the preparation and public review of environmental documents for private and public development. Under the law, private intervenors can argue that the environmental reports are inadequate and thereby delay project continuance until adequate information is supplied. The potential for local influence is further enhanced because local agencies dominate the regulatory process for geothermal development, thereby providing nearby access for citizen intervenors and ensuring some degree of responsiveness to citizen complaints. 


\section{State and Local Regulatory Agencies}

From a legal standpoint, the key regulatory agencies involved with environmental issues are the lead agencies for preparing Environmental Impact Reports (EIR)-the county government for exploration and development on private lands, the State Lands Commission for state lands, and and the State Energy Commission for plant certification-plus the responsible agencies that certify environmental documents and issue their own permits as well. ${ }^{11}$ Among the latter, the local Air Pollution Control Districts, Regional Water Quality Control Boards, and the State Department of Fish and Game are the most concerned with environmental issues.

The dominant actors in the regulatory process from the viewpoint of both legal powers and actual practice are the local regulatory agencies - the county governments, the local Air Pollution Control Districts, and the Regional Water Quality Control Boards. Each of these bodies has the power to confer or deny crucial permits at each stage of the development process (drilling and plant construction), whereas the other agencies play a more restricted role. ${ }^{12}$ Most county governments have jealously retained the right to issue a conditional use permit for each exploratory or production well as opposed to granting blanket use permits for large areas. ${ }^{13}$. Similarly, the local air pollution and water quality districts devise their own rules and procedures for enforcing state standards. They are not usually amenable to suggestions that state agencies impose standard enforcement practices on them, and the state agencies do not closely monitor those enforcement activities related to geothermal projects.

Whereas local governments and agencies actively seek to promote or to constrain geothermal development, state agencies have tended to be more interested in other energy sources. ${ }^{14}$ Furthermore, few of the state regulatory agencies have shown much interest in placing environmental restrictions on geothermal development; and those that have the interest lack the power to enforce compliance with their requests. ${ }^{15}$

The dominance of local agencies in regulating the environmental impacts of geothermal development is reinforced by the strong tradition of home rule in California. Even on federal lands, most counties seek to apply their own regulations over land use. Although the federal government has not officially recognized their

" Formerly, the California Public Utilities Commission certified power plants and had lead agency status for EIR reparation at that stage. The State Energy Commission now has those responsibilities.

12 The State Lands Commission issues leases and prospecting permits only; the California Department of Fish and Game does not have licensing authority over any wells or plants, and the Division of Oil and Gas has authority over wells but not power plants. The Public Utility Commission certifies power plants but not wells. Whether the State Energy Commission has jurisdiction over wells as well as plant siting is unclear; however, a recent task force report recommended that jurisdiction over wells, steam lines, and related facilities remain with the counties.

${ }^{13}$ Sonoma County did grant a blanket use permit for Union's entire leasehold at The Geysers, but this practice has not been repeated elsewhere.

14 Although the Governor's office and the Energy Commission have recently said they would like to treat geothermal as a preferred energy source, both recognize its limited potential for solving the state's energy problems.

1s The Department of Fish and Game is limited to requesting additional information before certifying environmental documents. The State Lands Commission typically avoids preparing its own EIR by adopting the county document when one is available. The Public Utilities Commission has never denied any permits to construct or operate geothermal plants. The Air Resources Board considers even uncontrolled geothermal plants much less polluting than controlled fossil fuel plants (interview at the ARB, April 6, 1977) and neither the State Air or Water Resources Board has ever revoked a local permit for geothermal wells or plants. Finally, the State Energy Commission has not exercised its new powers over the siting of geothermal power plants and so its posture toward geothermal development is still unclear. 
authority, most private developers have complied with county demands. Furthermore, federal law stipulates that where state air and water quality standards are as stringent as the national standards (as is the case in California), the state is responsible for local enforcement through its designated agencies. In California, enforcement of air and water quality standards is a local responsibility. Hence the local Air Pollution Control District and the Regional Water Quality Control Board issue their own permits on federal lands. ${ }^{16}$

\section{Industry and Federal Agencies}

The principal geothermal developers are those who drill the wells and lay the pipes (oil companies and small development firms) and those who operate the plants (utilities). Among the former, several are active in both the Imperial Valley and The Geysers. The principal utilities are, however, geographically bound: San Diego Gas and Electric (SDG\&E) and Southern California Edison are the major utilities backing power plant development in the Imperial Valley; Pacific Gas and Electric (PG\&E) is the only utility operating plants at The Geysers.

The Department of Interior (DOI) exercises the major federal influence on geothermal development: The Bureau of Land Management (BLM) leases federal lands and prepares the necessary EISs; U.S. Geological Survey carries out resource assessment and oversees development operations on federal leases. However, most development in California has occurred on nonfederal lands and DOI has had little influence on disputes in these areas. DOE, however, has played a role in such disputes as a result of its projects in the Imperial Valley and at The Geysers.

\section{CONFLICTS AT THE GEYSERS}

Although Sonoma is adjacent to Lake County, its residents do not complain about geothermal development, but Lake residents do. Why? The KGRA portion of Sonoma is also spectacularly beautiful and the air is as pristine as in Lake. But less than $\mathbf{5 0}$ people live in Sonoma's part of the KGRA and few tourists or hikers venture into its rugged mountains; hence few people see the plants, hear the drilling, or smell the gas.

In contrast, approximately 25,000 people live in Lake County, an area whose main sources of employment are tourism and agriculture. Many of Lake's citizens value the area's scenic beauty and quiet; others make their living from tourism and related services. Geothermal development diminishes the value of living in a quiet, underdeveloped, and highly scenic area-both for those who enjoy Lake's attractions for their own sake and for those who base their livelihood on tourism. These differences in citizen reactions to development in Sonoma and Lake Counties are reflected in the regulatory history of both areas.

\section{Regulation in Sonoma County}

Sonoma County's isolated geothermal operations cause its residents no envi-

\footnotetext{
16 Except when the operator is a federal agency. County and other local or state agency powers on federal lands are still in flux. But the trend has been and continues to be in the direction of greater local assertiveness with regard to the federal government.
} 
ronmental problems, and they constitute its largest single tax-paying entity. Sonoma County officials should therefore enthusiastically promote geothermal development and avoid attempting to mitigate its environmental impacts, and such has been the case. From 1960 to the present, Sonoma County has regulated geothermal development only in response to external stimuli-in particular, pressures from neighboring Lake County to reduce hydrogen sulfide emissions.

Before 1968, Sonoma County permits for exploratory and development wells were issued expeditiously, but well by well. In 1968, the Sonoma County Board of Zoning Adjustments streamlined this process and limited its own involvement in decisions regarding geothermal development by authorizing a blanket use permit for the 6,000 acre Union leasehold, thereby eliminating the need for action on each well.

By 1972, when eight units were producing $290 \mathrm{Mw}$ in Sonoma, the California Air Resources Board began receiving complaints from Lake County residents about odors drifting over the border. ${ }^{17}$ Complaints received by the ARB were directed to the Northern Sonoma Air Pollution Control Officer, who found The Geysers plant in violation of the state ambient air standards for hydrogen sulfide and issued an abatement order. Using the argument that abatement would cause economic hardship to the community, PG\&E applied to the NSAPCD Hearing Board for variances. The County's Board of Supervisors, who appoint the NSAPCD Hearing Board as well, saw no reason to jeopardize the substantial revenues the county receives from geothermal development. Hence, they granted the first variance on units 1 through 11 in 1974 for a period of four years. Subsequently, the board granted PG\&E additional variances through 1980.

These actions stimulated considerable resentment in Lake County, including frequent talk of filing a lawsuit against the Sonoma Board of Supervisors. ${ }^{18}$ Lake County officials, who have no control over source emissions in Sonoma, also put considerable pressure on the Northern Sonoma Air Pollution Control Officer to find a way to force PG\&E to retrofit its plants. The Northern Sonoma officer then had the unenviable task of trying to accommodate Lake's concerns and avoid being overruled by his own Hearing Board. The result was an ingenious compromise.

The NSAPCO negotiated retrofit schedules for the largest polluters (units 3 through 6) as a condition for permitting the construction of units 12,14, and 15 . The advantage of the conditional permit is that failure to meet the conditions is sufficient justification for the withdrawal of the permit. According to the NSAPCO, the Hearing Board does not have the power to grant variances on the conditions of the permit. PG\&E has now stepped up its retrofitting schedule and has designed several future units to use Stretford scrubbers. ${ }^{19}$

\section{Opposition to Development in Lake County}

Active opposition to development in Lake County can be divided into two

\footnotetext{
17 With the operation of Unit 8, a threshold level of odor may have been reached. In addition, siting plants below the inversion level interferes with the dissipation of hydrogen sulfide in the upper atmosphere (Tolmasoff, 1976), and all of PG\&E's early units are. located below the inversion level.

1s The ire of Lake County residents at air pollution spillovers from plants in Sonoma is exacerbated because they pay environmental costs but receive no benefit from the plants. Revenues from geothermal taxes go to Sonoma but the odors waft over the mountains to Lake County. In addition, Lake County gets its electricity from hydroelectric power, not from the geothermal operations at The Geyers.

io The Stretford scrubber cannot be used with existing units equipped with direct contact condensers.
} 
periods. Before the application of CEQA to all discretionary acts of government in 1973 , the opponent to geothermal development had only one recourse-to try to influence the Planning Commission or the Board of Supervisors not to grant use permits. CEQA afforded opponents more opportunities to intervene, more access to information, and a basis upon which to sue or seek injunctions. ${ }^{20}$

The Mount Konocti Case. In 1965, Imperial Magma began drilling at the foot of Mt. Konocti, an extinct volcano that is one of the most prominent and scenic features of Clear Lake's southern shore. Controversy over Magma's drilling led to the formation of the Lake County Geothermal Control Council, which protested against development at $\mathrm{Mt}$. Konocti. However, although three companies undertook exploratory drilling at the site, the results were negative. Drilling at this site was then abandoned and the Lake County Geothermal Control Council died for lack of an issue.

From 1965 to 1973, drilling activity in Lake County centered around Anderson Springs, which is hidden from the highway and not a major recreational area. Sporadic individual protests, but no organized opposition, arose over this activity.

The Cobb Mountain Case. In 1975, Union Oil obtained permits to drill at its Cobb Mountain leasehold. Again, a local organization-Friends of Cobb Mountain -emerged to contest Union's activity. By now CEQA applied to geothermal operations, affording environmentalists the opportunity to turn to the courts to try to stop the drilling. Pollution spillovers from Sonoma County had also raised concerns about geothermal development. In concert with the Sierra Club and the Environmental Defense Fund, Friends of Cobb Mountain filed a suit challenging the adequacy of the EIR under CEQA. The suit was lost at the Superior Court level and went to the Appeals Court. When the environmental groups could not get an injunction to halt the exploration pending resolution, they dropped the suit. Because of pre-existing drilling commitments, Union did not proceed with the exploration until the summer of 1976.

Mt. Konocti Revisited. In 1975 Magma again applied for a use permit for drilling on the slopes of Mt. Konocti. The Planning Commission certified the adequacy of the EIR but denied the use permit on the grounds that Mt. Konocti was too sensitive for development -its scenic and recreational values should not be endangered. This decision was reached after several months of public hearings, during which citizen opposition to development at Mt. Konocti was vehemently expressed. At this point, Magma appealed the decision to the Board of Supervisors, two of whom had leased their own land for geothermal development. The Board of Supervisors subsequently overruled the Planning Commission and granted permits for two exploratory wells.

The Board's action inflamed the environmentalists and led directly to the formation of the Lake County Energy Council, an organization with a membership of 1,100. The council filed suit in Superior Court in May 1976 on the grounds that a full development EIR was required and Magma had not adequately considered the alternatives to the project. The case was lost in Superior Court, appealed and again decided in favor of the developer in June 1977. Because the Magma venture was

\footnotetext{
${ }^{20} \mathrm{CEQA}$ requires a lead agency to collect and make available for review all information pertinent to the true and expected consequences of a proposed development. Although the law does not seek to control environmental damage directly, an individual or agency may sue the lead agency and seek an injunction on the grounds that all relevant information has not been included in the report.
} 
intended to supply power to the Sacramento River complex, which Dow has abandoned, it is unclear whether Magma intends to go ahead with the exploration. Magma has currently suspended operations in the area.

In late 1976, the Lake County Energy Council filed another suit against the county. Once again the issue was the adequacy of an EIR for a Union project at Thurston Lake, directly south of lower Clear Lake.

The preceding history illustrates the importance of local organizations in spearheading active opposition to development in Lake County. Although the Sierra Club was involved in early protests, local organizations have figured in each major contest. Currently the Sierra Club has withdrawn from the arena, relying on the Lake County Energy Council to continue the battle, and the Council has readily taken the lead in disseminating information to concerned citizens, developing strategies of opposition and filing court suits.

The opposition to geothermal development has not prevented any development, but it has succeeded in delaying some projects and in making environmental concerns apparent to Lake County citizens and officials alike. Each instance of opposition to a specific proposal has reinforced the legitimacy of environmental concerns and enhanced the citizens' ability to identify and protect their interests. Each case has also demonstrated that an organizational base can be mobilized and effectively used to delay development when an issue arises.

\section{Signs of Accommodation at The Geysers}

Sonoma County's accommodation to Lake County's environmental concerns has been repeated elsewhere. PG\&E has stepped up its retrofitting schedule, financed several studies of air quality in the area, and is testing a new copper sulfate process for hydrogen sulphide abatement under a contract with DOE. ${ }^{21}$ The Lake County Air Pollution Control Director has organized several environmental seminars that have brought together federal, state, and local officials, plus developers and private individuals for information exchange. Of special significance is the four-county commission created to oversee a comprehensive environmental study for The Geysers KGRA. This commission includes one member from each county's Board of Supervisors plus representatives from the California Energy Commission and DOE. ${ }^{22}$ DOE and the State Energy Commission are jointly contributing approximately $\$ 50,000$ for a planning grant that is to identify the environmental data required for designating geothermal development areas in the four counties.

The story behind the commission's creation provides useful lessons for federal involvement in local environmental conflicts. Recognizing that opposition to uncontrolled development was intense and that the project-by-project approach to issuing

21 To date PG\&E has financed, or partially financed along with other geothermal developers, the following studies: Swanson \& $\mathrm{Mooney}_{2} \mathrm{~S}$ Survey of 1972 (at the request of the State ARB), Altshuler Air Quality Study (on-going since 1970), Unit 11 Monitoring (at the request of CPUC and NSAPCD), and the Stanford Research Institute $\mathrm{H}_{2} \mathrm{~S}$ Transport Study (at the request of LCAPCD as a condition for the granting of the Authority to Construct Unit 13). The SRI study has $\$ 800,000$ in funding from PG\&E and several other developers. It is expected to last two years and to yield sufficient data on $\mathrm{H}_{2} \mathrm{~S}$ transport patterns to inform development decisionmaking in all of the lower portion of the KGRA (Tolmasoff, 1976).

22 The four counties are Sonoma, Lake, Napa, and Mendocino. ERDA originally negotiated the arrangements; when DOE absorbed ERDA, it took over the defunct agency's responsibilities. 
permits was both administratively costly and unlikely to alleviate environmental concerns, Lake County established a trust fund of $\$ 10,000$ for an integrated assessment plan in October 1976. Lacking sufficient funds to carry out the job on its own, Lake officials sought additional support from federal and state officials. ERDA indicated that funding might be provided if the Lake County plan were expanded to include all four counties in the region. Responding to this initiative, Lake officials initiated a four-county coordination meeting. By May of 1977 , all four counties had passed resolutions suporting a Geothermal Resource Impact Projection Study (GRIPS), the commission had been formed, and the \$50,000 acquired from ERDA and the State Energy Commission.

This commission brought together four very different jurisdictions: two counties with a history of conflictual relations (Sonoma and Lake), a third that had prohibited all but exploratory drilling for a substantial period (Napa), and a fourth that had not yet instituted a process for dealing with geothermal development (Mendocino). Its formation can be attributed largely to the attraction of receiving federal and state funding for planning that none of the counties could finance on their own. And much of the credit for facilitating this step toward inter-governmental cooperation goes to ERDA for requiring a regional approach as a condition for receiving funds.

Nevertheless, ERDA's positive role in facilitating the creation of the GRIPS Commission was not lauded by any of the agencies involved. Both the counties and the State Energy Commission felt that ERDA's actions were motivated by its own organizational imperatives-installing Lawrence Livermore Laboratory (LLL) as the project manager for GRIPS. But the counties are strongly opposed to direct federal intervention in their affairs and feared that if LLL undertook the project they would lose control over its design and end use. ${ }^{23}$ Hence they strenuously fought for (and won) the right to choose their own consultant and to determine the acceptability of proposed study activities."

In the end, ERDA funded its own independent analysis of the existing environmental data base and additional data needs in The Geysers area. But the project's managers overcame much of the earlier hostility toward LLL and DOE by working with the GRIPS Commission (as well as its consultant) to identify environmental concerns, existing data, and future strategies. They did this by conducting joint environmental workshops with GRIPS and bringing together representatives of industry, all three levels of government, and local environmentalists.

These steps are only the beginning of a concerted effort to develop The Geysers' geothermal resources in an environmentally acceptable manner, but they do signal the birth of a more cooperative climate among the principal actors involved in geothermal operations there. The costs to all sides of protracted negotiations seem to have provided incentives for accommodation.

\footnotetext{
* The counties' perceptions of ERDA's motives are supported by three facts: (1) ERDA strongly pushed a management plan under which LIL would be designated as project coordinator, suggesting that only that approach would be likely to receive funding in fiscal year 1977/1978; (2) ERDA limited its initial GRIPS funding to $\$ 20,000$; and (3) ERDA funded an independent LLL analysis of environmental data needs at The Geyser.

s4 ERDA officials state that they wanted LLL to manage the environmental overview function only (identifying environmental issues, assessing available data, and identifying data gaps); county officials interpreted overview management as synonymous with heading the overall planning effort.
} 


\section{DEVELOPMENT IN THE IMPERIAL VALLEY}

Geothermal development in the Imperial Valley is still in its infancy. Despite a history of drilling going back 50 years, no commercial plants producing electricity from geothermal resources have yet been constructed. Underlying this lack of development are technical and economic uncertainties related to the demonstration of wet reservoir conversion machinery capable of handling highly saline brines, the development of adequate cooling water sources, and the disposal of large volumes of waste brines.

Efforts to reduce these uncertainties quickened during the 1970s. Several oil companies and independent firms have tapped geothermal reservoirs; SDG\&E and Imperial Magma have been operating an experimental $10 \mathrm{Mw}(\mathrm{e})$ facility near the Salton Sea since 1976; and two $50 \mathrm{Mw}(\mathrm{e})$ plants are currently planned for the Heber and East Mesa areas.

\section{County Attitudes Toward Development}

Public opposition to geothermal development in Imperial County has been negligible and short-lived, consisting of sporadic, individual protests rather than an organized collective effort. ${ }^{25}$ In general, the public is favorably disposed toward geothermal development, but that posture rests on limited knowledge. In a survey of residents conducted by the county, only one-fifth felt they had a good understanding of what it is and less than one-tenth felt that the citizens have been adequately informed about it (Imperial County, 1977).

Official attitudes are more crystallized: Both elected and appointed officials tend to view the resource as a potential source of revenues and want to promote its development. As a consequence, securing permits and certifying environmental assessments generally takes less time and costs less in Imperial County than at The Geysers.

County officials have also expressed concern about controlling geothermal development, minimizing environmental impacts, and preserving the area's basic agricultural economy. Imperial is the only county in California that has developed a geothermal element for its general plan and zoning ordinances for geothermal projects. The draft plan calls for a Master EIR that would be incorporated into separate project reports for review of siting to minimize effects on agriculture; for the exploration of alternative methods of taxing the resource; and for the development of new standards (or the application of existing standards) dealing with air quality, noise levels, drift, thermal emissions, and other potentially hazardous effects (Imperial County, 1977).

Imperial County's environmentally conscious planning efforts differ from The Geysers' pattern of responding to problems after they have generated public controversy. Although we lack the necessary data to judge whether such anticipatory actions have actually forestalled citizen opposition to geothermal development, it seems reasonable to predict that successful efforts to prevent adverse effects would also lessen future opposition. Imperial County's efforts to create geothermal zones,

\footnotetext{
${ }^{25}$ We have uncovered only two instances of geothermally related complaints: one by an unaffiliated individual and one by a now-defunct organization. The first argued that a county plan and guidelines should precede all development and the second was based upon a mistaken belief that geothermal brines would be discharged into the Salton Sea.
} 
minimize adverse effects on agriculture, and develop emission standards will probably mitigate future adverse effects attributable to geothermal development and thus reduce the likelihood of significant opposition emerging in the future. DOE's work to reduce uncertainties about the potential environmental impacts of geothermal development complements the county's posture.

\section{DOE's Activity in the Imperial Valley.}

DOE's major activity in the valley has been through the Imperial Valley Environmental Project (IVEP), an ERDA-initiated effort to provide baseline environmental data with which the effects of actual development can be compared. The purpose of the project was to understand the environmental quality in the Imperial Valley before any major geothermal resource development so that future activities could proceed on an environmentally sound basis (Anspaugh and Phelps, 1976a). For example, the IVEP has provided new information on the effects of hydrogen sulfide emissions on plant life, set up subsidence networks and air monitoring stations for establishing baseline conditions and monitoring future changes, and is developing a method for detecting the presence of geothermal brines in surface and ground water. ERDA funded the project, Lawrence Livermore Laboratory managed and carried out the research on a daily basis, and representatives from ERDA/DOE's San.Francisco and Washington headquarters provided management . coordination.

ERDA's work in the valley stemmed from its commitment to help finance SDG\&E's test facility at Niland; it also agreed to provide the environmental research necessary to support the test facility and a possible $500 \mathrm{Mw}(\mathrm{e})$ capacity in each of the valley's four major KGRAs. This initial arrangement was with SDG\&E alone; it did not include local officials nor did it specify an integrated valley-wide assessment. The latter concept was developed by ERDA and LLL.

The way the IVEP was initiated could have generated considerable local resentment against ERDA and severely hindered its ability to do the job it had set out to do. It is not difficult to imagine a situation clouded by local frustration and complaints - against federal intrusion, insensitivity to local problems, and a condescending attitude of "we know what's good for you even if you don't.".

None of this occurred, in part because project managers did not go ahead with a regional concept until they had consulted local interests, and in part because local officials were interested and involved in an NSF-funded study designed to produce the county's geothermal element. During the actual research process, the IVEP continued to develop cooperative relationships with public officials, industry, and appropriate research bodies. These endeavors took three forms: (1) formal and informal communication through workshops, meetings, and phone contacts; (2) contractual transfers of money from LLL to individuals or groups to carry out part of the research; and (3) cooperative exchanges not typically involving monetary transactions. ${ }^{28}$

The result has been remarkable local satisfaction with the project's goals and progress. Throughout our interviews in the valley, we heard no criticism of the

\footnotetext{
26 For example, Union allowed LLL access to its wells in exchange for getting an air quality station located near its development; the Imperial Irrigation District provided LLL with detailed records on its irrigation and drainage canal system and in turn receives LLL's data on the chemical composition of canal waters.
} 
project's objectives, methods, or relationships. This local acceptance appears largely attributable to the project managers-to their understanding of the local context as well as their efforts to involve local interests in project planning and implementation.

Organizational features that have contributed to the project's success include:

- Promotion and support of the project at headquarters,

- Clear lines of communication, and

- Capacity to adapt to changing conditions.

Headquarters Support of the Project. There has been solid support for the IVEP from DOE's Washington headquarters, evidenced by considerable delegation of decisionmaking responsibility and the ability to expend funds, both of which are crucial to the project's effectiveness. LLL could issue research subcontracts more quickly than headquarters, and LLL and DOE's San Francisco Operations Office (SAN) together were in a better position to assess subcontractor capabilities. It is also important that the project had someone on site who could speak with authority for headquarters. Without the responsibility for making key decisions and the authority to back them up with the force of the funding agency, efforts by the Lab and field offices to solicit local inputs would have been meaningless.

Clear Lines of Communication. The lines of communication among the three offices-LLL, SAN, and headquarters-were clear and frequently used. Each office had someone who was responsible for the project and who could insure continuity and coordination. Phone calls occurred almost daily; in addition, the principal coordinators often met to decide crucial points of project initiation and continuity.

Clear communication channels would be irrelevant if they were not continually used and buttressed by cooperation among the three coordinators. It was this willingness to work together to solve problems and to trust others to do their jobs-this realization of the substance, as opposed to the form, of real communication-that made the project oganizationally effective.

Adaptability to Changing Conditions. From the beginning, the IVEP had been an innovative organizational experiment involving a series of first-time endeavors-the diversion of funds from other projects, the launching of a highly technical laboratory into site-specific field work, and the melding together of three disparate organizational units. These innovative beginnings set the stage for an adaptive approach to problem-solving that continued throughout the project. In large part, flexibility and adaptability have allowed the project staff to build working relationships in the valley, respond to local concerns, and build support for the research.

These features, combined with sensitivity to local concerns and participation by local interests in project planning and implementation, appear to account for the IVEP's acceptance in the valley as well as its success in developing an informational and communications network within which future uncertainties and conflicts might be resolved. 


\section{ENVIRONMENTAL DISPUTES IN OIL SHALE DEVELOPMENT}

Shale oil is derived from fossil organic matter (kerogen) trapped within layers of rock. When the rock is heated ("retorted"), the kerogen is released as vapors. After condensation and treatment, these vapors form a synthetic crude oil that substitutes for conventional petroleum crude. The world's richest deposits of oil shale are found in a sparsely populated, semi-arid plateau region of southern Wyoming, northeastern Utah, and western Colorado (as shown in Fig. 2). About
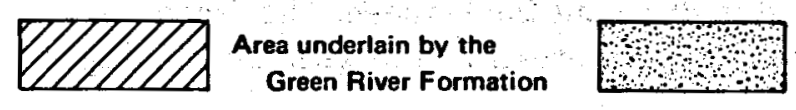

Approximate extent of selected minable seam in the Mahogany Zone lat least 30 feet thick and averaging st least 30 gal./ton).

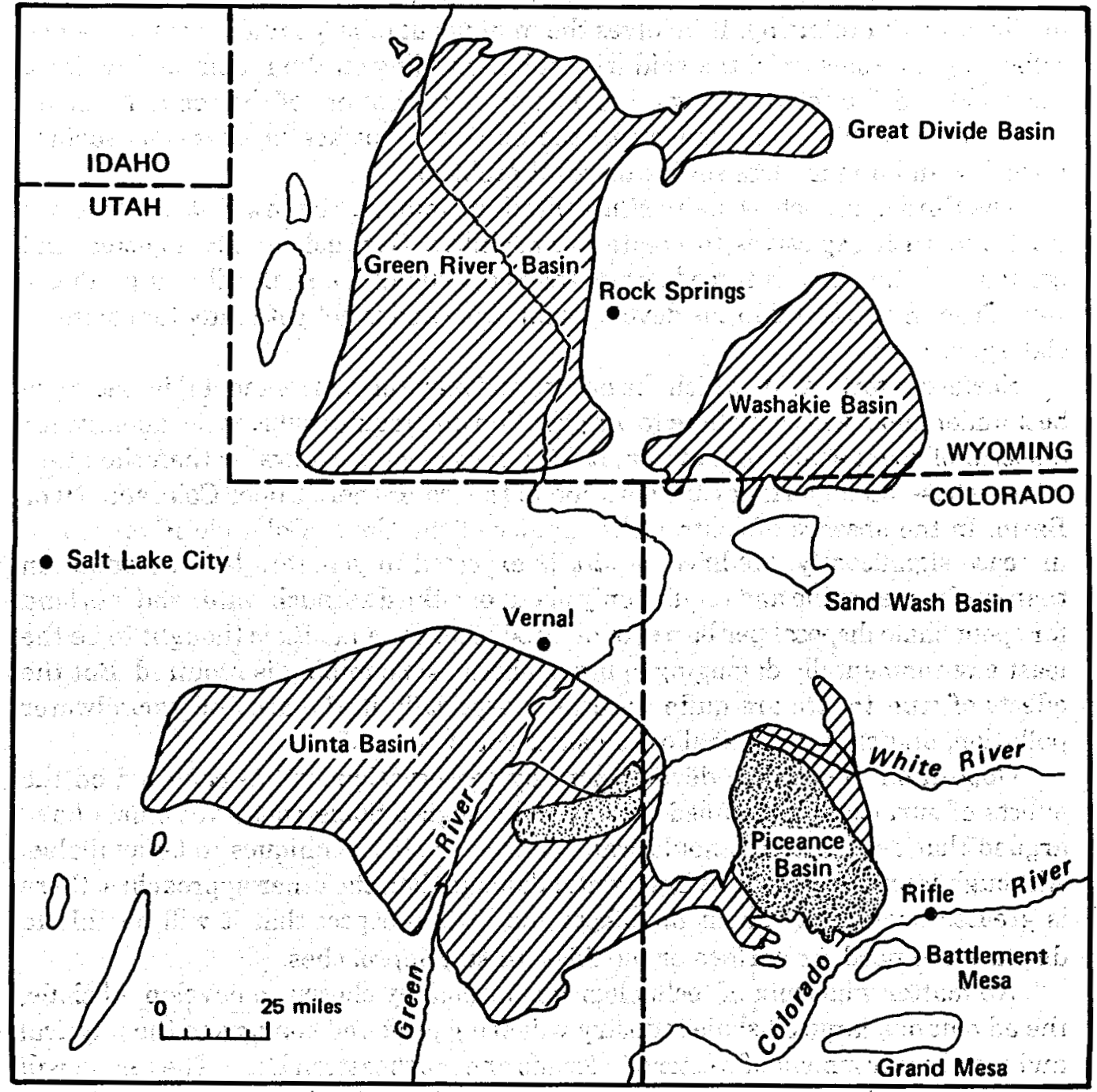

Fig. 2 - Location of oil shale deposits in Colorado, Utati and Wyoming *

- National Petroleum Council, National Energy Outlook: Oil Shale Availability, 1973, p. 11. 
four-fifths of the richest and most accessible deposits are found in Garfield and Rio Blanco Counties in Colorado, with almost all remaining high-grade accessible deposits located in Uinta County, Utah. Oil shale is a vast potential reserve of liquid hydrocarbons. If produced successfully, it could augment U.S. oil reserves for many years. Although no shale oil is yet being commercially produced in the United States, oil company interest dates back more than 20 years.

\section{TECHNOLOGIES AND IMPACTS}

Three types of technologies are being seriously considered for the extraction of shale oil. The most fully developed of these are surface retorting processes, which entail mining the stratum of rock rich in kerogen and conveying it to large vessels (retorts) in which the rock is heated to drive out the kerogen. The "spent" shale must then be disposed of. Surface retorting requires a very large mining and spent shale disposal effort.

The second approach, which is nearing commercial availability, is called modified in situ retorting. It involves the mining out of large underground rooms, collapsing the roofs to fill the void with rubble, sealing off the rooms, and igniting the shale to drive the resulting oil to a sump at the bottom of the room. Modified in situ entails only about one-fourth the mining of surface processes as surface retorting and a much less severe disposal problem.

The third approach-true in situ - entails no mining. Shallow beds of shale are fractured with explosives to create permeability. Gas and air are injected and ignited and the flame is forced across the bed, driving the shale oil to a producer well. True in situ is still in the development stage and is not yet ready for commercial application.

Surface retorting, for which the nature and scope of environmental impacts are best understood, will contribute to air pollution and require substantial acreage for disposal of spent shale. In addition, it consumes much more water than the other approaches-an important consideration in the water-short Upper Colorado River Basin. In the absence of control, the salinity of the Upper Colorado River would increase significantly. Modified in situ is expected to generate less air pollution than surface retorting and require only about one-third as much water and less land for spent shale disposal per barrel of oil produced. True in situ is thought to be the least environmentally damaging approach because no mining is required. But the effects of true in situ are quite uncertain, especially in the area of groundwater pollution, and only fairly shallow deposits could be used.

Opposition to oil shale development by conservationists has centered on the effects of surface and modified in situ technologies. Some conservationists have argued that development should wait for true in situ techniques to be available. Although it promises less environmental damage than the other approaches, there is greater uncertainty about its effects and little prospect that it will be able to displace the need for surface or modified in situ approaches.

No matter what mix of technologies is ultimately chosen to develop oil shale, the advent of a large oil shale industry will bring profound changes to the physical and social environment of western Colorado and northeastern Utah. The region will be transformed from a rural, often pristine environment into one supporting at 
least one major industry and probably several secondary ones. With the possible exception of water quality, the adverse environmental impacts would be restricted to the Upper Colorado River Basin. Because of the topography of the Western Slope, spillovers of air pollution to eastern slope counties are not expected.

\section{ACTORS}

Disputes over the environmental impacts of oil shale development have involved a large number of parties. The most important have been the U.S. Department of the Interior, conservationist groups located in Denver, oil companies with an interest in oil shale development, and the state and local governments. ERDA played a role as the lead agency for the Synthetic Fuels Commercial Demonstration Program that failed passage in 1975 and 1976 but has played only a minor role in on-site disputes.

The Rocky Mountain region has a number of active conservationist groups, with the most active and well-organized being located in Denver. These groups, some of which can call upon the resources of their parent national organizations for support, have been the most active opponents of oil shale development. In the immediate vicinity of development, no environmental opposition has surfaced at this point, although there is a potential for conflict.

The principal potential developers are oil companies, some of whom have invested $R \& D$ funds in developing oil shale technologies over the past two decades. Oil companies formed a number of consortia to share development and investment costs and to bid on federal leases.

The states of Colorado and Utah have vital interests at stake in oil shale development. Because of its potential size, the oil shale industry will have statewide effects in terms of investment, jobs, environmental effects, and water consumption. Taxes, revenues, and demand for services would be affected by the pace and extent of development. Utah has been generally very supportive of accelerating oil shale development, but the Colorado government has in the past few years called for a more cautious approach.

To understand the different attitudes in these neighboring states toward development one must consider the political cultures of the states. Colorado's population is heavily concentrated in the eastern counties. The greater Denver area alone contains about one-half of the state's 2.5 million population. Denver itself is a center of support for liberal causes, and almost all environmental groups are headquartered in the city. The political parties in Colorado are about evenly balanced in strength and quite issue-oriented. In general, the Republican party has stressed energy development and the Democrats have argued for more environmental controls. Utah, by contrast, is ethnically, politically, and socially quite homogeneous, with the political tone, if not the substance, influenced by the Mormon Church. Political parties are competitive, but there is agreement on most major issues affecting energy and the environment.

The three counties that will be most affected by shale development (Garfield and Rio Blanco in Colorado and Uinta in Utah) are rural, sparsely populated, and poor. Limited irrigated agriculture, oil and gas extraction, and tourism are the mainstays of the local economies. At the present time there is no discernible opposi- 
tion to oil shale development among the local governments and citizens in the immediate areas of development. Local governments view oil shale development as fostering and accelerating the economic development of the area. Conservationists are viewed as "outsiders" who lack a legitimate interest in shale development. Local governments in the shale area have not yet been subjected to much demand for services. Oil shale development could change that, and one of the county governments has taken steps to gain a measure of control over development. There may be a potential for conflict between local residents and oil shale developers even though local opposition to development has not yet materialized.

The U.S. Department of the Interior (DOI) has been deeply involved in oil shale development efforts primarily because the federal government owns about 80 percent of the oil shale reserve, which the Department administers through the Bureau of Land Management. Over the years DOI has also been a major funder of research into retorting methods and through the Bureau of Reclamation controls a great deal of the water that might be used by an oil shale industry. DOI's effort to begin leasing oil shale lands through the Prototype Oil Shale Leasing Program has been the focus of a number of environmental disputes.

\section{EXAMPLES OF CONFLICT AND COOPERATION}

Concern over the environmental impacts of oil shale development has been expressed by scientists and conservationists ever since development of western shale was first seriously contemplated in the 1950 s. Significant environmental opposition from citizens' groups did not develop until the preparation for the Prototype Oil Shale Program began in 1969. Planning for the Prototype Program coincided with the national upswing in environmental concern and passage of the National Environmental Policy Act (NEPA) in 1969.

Because of federal ownership of most rich shale deposits and the geographical concentration of the resource, most disputes discussed below have involved the federal government. However, some disputes concerning shale development on private lands did not spring from federal policies and offer a useful contrast.

\section{Early Conflicts in the Prototype Program}

After 1930, no federal oil shale lands were leased until pressure from industry and state governments started to build for new leasing in the 1960s. When a proposed leasing program was submitted to Interior Secretary Hickel in 1970, he postponed announcement of a leasing program pending further environmental study. This resulted in a Governor's Committee made up of representatives of state and federal government and industry, but not conservationists. The report of the Governor's Committee was the basis for the draft environmental impact statement for the Prototype Program that was released when new Interior Secretary Morton announced the program in 1971.

Because industry representatives had been included on the Governor's Committee, several environmental groups in Denver felt their exclusion was inappropriate and objected vigorously. Conservationists believed that NEPA granted them access to decisionmakers at least coequal with industry access. Interior, however, felt that they had offered extraordinary access to the process. DOI held 25 public 
meetings and field trips to the shale area and felt they complied with both the spirit and letter of the newly enacted NEPA. These wide differences in perceptions recurred repeatedly throughout the Prototype Program.

The differences appear to have resulted from several factors: (1) a lack of trust of the goals and motives of the other parties (some at DOI felt that conservationists were united to kill the Prototype Program regardless of environmental protection measures taken, and some conservationists felt that DOI would develop oil shale at any environmental cost); (2) a lack of agreement about what "access to decisionmaking" means; and (3) the fact that major program decisions and the EIS preparation were conducted in Washington with only a field representative to gather and disseminate information in Denver.

\section{Disputes over the Environmental Impact Statements}

Not surprisingly, the NEPA requirement for an environmental impact statement became a focus of continuing controversy among conservationists, DOI, and industry. The first draft EIS issued in 1971 was widely criticized and thereafter labeled a "preliminary" draft.

A new environmental analysis funded by Colorado state and local governments, DOI, and oil shale developers was begun shortly thereafter, and conservationists were included on each subcommittee. Unfortunately, DOI wrote the final draft EIS with little reference to this effort (interim reports were available) and also made a final decision to begin leasing before the investigations were completed. This time both conservationists and the state were unhappy with having been excluded from decisionmaking on the program.

The complaints about the final draft and the final EIS echoed complaints typical of impact statements generally: no priorities, too long, poorly organized, too many words and too little analysis. In addition, conservationists, local and state government officials complained that they were not given enough time to read and respond to the material in the statement. By the time of the decision to proceed with leasing (November 1973) the Arab oil embargo was on, and DOI was beginning to respond to a perceived crisis. Even before the embargo, however, DOI seemed to believe that time was of the essence.

\section{Leasing and the Energy Crisis}

Between January and June of 1974 two tracts were leased in Colorado and two in Utah with the total bonus bids amounting to nearly $\$ 450$ million. The bids were much higher than DOI originally expected because the oil embargo and energy crisis had intervened in the months before. Conservationists objected to the wide discretion that the lease terms delegated to the Area Oil Shale Supervisor (AOSS) for approving the adequacy of environmental protection measures to be taken by the lessees. Of most importance to the already strained relationship between conservationists and DOI were the contingency plans for oil shale development drawn up by DOI as part of Project Independence. These plans were leaked to the press and called for a very rapid buildup of an oil shale industry and a relaxation of environmental standards. They would have undermined the raison d'etre of the Prototype Program and confirmed conservationists' fears that the Program was a subterfuge for a massive industry buildup. These fears were heightened further by 
the Synthetic Fuels Commercial Demonstration Program legislation introduced in 1975. The result was that many conservation groups gradually shifted from opposing particular substantive actions to complete opposition to the program.

The Lease Suspensions. Although conservation groups had repeatedly threatened lawsuits over various aspects of oil shale development, no lawsuit actually materialized until the Prototype Program lessees requested and were granted suspensions of the requirement that they make payments on their leases in 1976. Under the Minerals Leasing Act, the Secretary of the Interior can suspend leases, and therefore the requirements for payment, for "reasons of conservation." The companies requested the suspensions on the basis that air quality standards could not be met. A number of conservation groups headed by the Environmental Defense Fund filed suit against the Secretary and the AOSS claiming that the reason behind the suspensions was unfavorable economics, not conservation, and therefore the suspensions were illegal. Conservationists also alleged that the suspensions fell under the provisions of NEPA requiring an environmental impact statement. It was the hope and assumption of conservationists that if the suspensions were overturned, the companies would relinquish their leases, thus ending the Prototype Program. Although the suit was dismissed on a technicality, conservationists continue to watch the progress of the Prototype Program and have petitioned Interior Secretary Andrus to terminate it and start over.

Cooperation on the Oil Shale Environmental Advisory Panel. A striking aspect of the Prototype Program experience is that from 1969 (when program planning began) to the present, representatives of the industry and of conservationist organizations have never met to discuss whether their differences could be bridged. Both industry and conservationists have looked upon DOI as representing the interests of the other. The only partial exception was the Oil Shale Environmental Advisory Panel (OSEAP) organized by DOI to advise the AOSS on environmental problems.

The OSEAP membership is drawn primarily from DOI and other federal agencies, but it also includes representatives of state and local government and two private citizens who are members of a conservationist group. Although conservationist membership is limited and industry is not formally represented, the panel has been useful in defining the most important environmental issues for the AOSS. However, the effectiveness of the OSEAP as a means of bringing conservationists and industry together has been limited by the small conservationist representation on the panel and the lack of formal industry representation.

The Colony Development Case. A second, more prominent example of cooperation between conservationists and industry grew out of the Colony Development Operation's preparation for development of privately owned shale lands in Colorado in 1973-74.

Starting in 1972 and extending until Colony's plans were indefinitely suspended in the fall of 1974 for economic reasons, Colony's Denver office maintained regular informal contacts with conservationist groups. As part of its preparation for development, Colony conducted a $\$ 3$ million program of environmental impact research. The contacts with conservationists highlighted areas that may have been neglected in Colony's research program and that were of greatest concern to conservationists.

In April 1974, Colony held a symposium in Denver with conservationists, state and local government officials, and representatives of federal agencies to discuss 
the results of its environmental research and its plans for environmental protection for its proposed commercial facility. Twenty conservationists and citizens' groups were represented among the participants. When Colony Development suspended its plans in late 1974, contacts with conservationists were similarly suspended.

Because the Colony facility was not constructed as scheduled, it is impossible to determine whether the dialogue would have actually resulted in fewer disputes between the company and conservationists. What is significant about the Colony case, however, is that in meeting face to face, developers and conservationists were able to discuss substantive issues and get a much better understanding of mutual concerns than would have occurred otherwise. Progress was made in defining issues and ordering the importance of issues-a crucial step toward compromise solutions. Colony considered its contacts with conservationists to be good business sense as well as socially responsible. In Colony's view, compromising with environmental groups would ultimately prove to be less costly than being sued by a united conservation movement. For conservationists it was an opportunity to be heard and possibly influence decisions.

Colony is not the only potential shale developer on private lands. Should oil shale economics improve, both the TOSCO Sandwash project and the Superior Oil Company multi-mineral project would be activated on private lands with only tangential federal involvement. Conservationists have long urged that private holdings be developed first to prove the economic and environmental acceptability of oil shale before the massive federal holdings are released. Should such private holdings be developed first, except for the prototype leases, the Colony experience would be particularly relevant to oil shale's future.

\section{OIL SHALE AND INTERGOVERNMENTAL DISPUTES}

Federal actions to stimulate oil shale commercialization have from time to time raised tension between state and local governments on one hand and the federal government on the other. The most prominent disputes have involved the federal government and the state of Colorado. In 1974, Democrat Richard Lamm ran successfully for governor promising to increase the state's control over energy development to prevent deleterious environmental effects. The Lamm administration objected vigorously to a lack of consultation on the 1975 Synfuels legislation and even more strenuously to DOI's failure to consult with the state regarding the lease suspensions. The State Attorney General even recommended that Colorado join with conservationists in their suit against DOI. Although the Lamm administration is much less hostile toward development than conservationists as a whole, the strained relations with federal agencies have one important common element: the perception of being closed out of the bureaucratic decisionmaking process.

The Lamm administration has not been completely without success in its dealings with the federal government concerning oil shale development. The Synfuels bill introduced in 1976 was modified at Lamm's urging to include a small oil shale demonstration to test environmental effects; and more significant, Secretary Andrus agreed to give Colorado a substantial say in the allocation of federal reclamation project water to energy projects, including shale.

Utah's relationship with the federal government, and with DOI in particular, is similar in form to that of Colorado but radically different in substance. Utah 
officials complain that the federal government is seriously delaying energy development in the state by overly restrictive environmental regulations. Utah also recently sued the federal government for ownership of most of the oil shale lands in the state, including the tracts leased under the Prototype Program. Utah claims this land in lieu of land for schools that the federal government was unable to grant at statehood. If the lands controversy is ultimately settled in Utah's favor, the state would probably seek to accelerate shale development in the Uinta Basin.

With the exception of Rio Blanco County, local governments have not played much of a role in oil shale development disputes to date. Rio Blanco, however, has taken a series of actions designed to assert some measure of control over the potential "boom town" effects that could result from the construction and operation of oil shale plants. Unfortunate experiences in neighboring Wyoming and Montana and in Colorado itself have convinced county officials of the need to take action. The county has rezoned all unused lands (including federally owned oil shale lands) for agricultural use only unless a variance is granted. DOI does not officially recognize the county's authority over federal lands but has urged developers to apply for county permits anyway. In addition, the county has negotiated directly with DOI over the placement of housing in the county for oil shale and signed a memorandum of understanding on the issue. The county has also obtained financial assistance for planning activities from Prototype tract lessees. These funds have aided the county in developing a master plan for the county's development. It is important to note that Rio Blanco's assertiveness is not symptomatic of opposition to development. Rather it is a desire to see that development benefits the county as much as possible. Implicit in the county's actions, however, is the threat that if the county's needs are not met, opposition might develop.

In summary, oil shale development to date has been marked by generally contentious and non-cooperative relationships between government and private citizen conservationists and between governments. Examples of cooperation-the Colony case and the OSEAP - are exceptions. In the absence of basic changes, the prognosis is for continuing and costly conflict in oil shale shale development. 


\section{IV, PRINCIPAL FINDINGS}

Our analysis of geothermal and oil shale development leads to several conclusions about the emergence and resolution of environmental problems. These conclusions apply to conflicts that are roughly symmetrical, in which both sides perceive the costs of losing to be significant. The discussion below divides these conclusions into three categories-factors that affect tradeoffs between environmental and energy goals, sources of opposition to energy projects, and the process of conflict resolution.

\section{FACTORS AFFECTING ENVIRONMENTAL/ENERGY TRADEOFFS}

- Tradeoffs between environmental and energy goals are technology and project specific. They depend upon (1) state and local divisions of authority and degree of concern about energy outcomes, (2) the demographic context, (3) the availability of existing institutions for the resolution of conflict, and (4) the past experience and present interaction of parties to the conflict.

The major environmental problems associated with producing electricity from geothermal steam-land degradation, hydrogen sulfide emissions, and noise-differ from those likely to be encountered when the use of hot brines becomes commercially viable. Similarly, surface retorting and modified in situ techniques entail a large mining and shale disposal effort that is not required with "true" in situ retorting. These differences mean that regulations, abatement techniques, and planning guidelines suitable for one type of geothermal or oil shale development cannot be easily transferred to another.

\section{State and Local Differences}

To date, the states of Colorado and Utah have exerted more influence on oil shale development than have the counties; in contrast, California counties have had more effect on geothermal development than has the state. Three realities contribute to this difference: (1) the economic and environmental stakes are greater for oil shale than for geothermal development; (2) California counties have a more entrenched history of local autonomy than do counties in Utah and Colorado; and (3) extensive federal ownership of oil shale land (over 80 percent) intensifies concern over federal encroachment on states' rights in the Rocky Mountain region. ${ }^{1}$ The

\footnotetext{
1 Geothermal energy is unlikely to supply more than 5 percent of California's energy needs, whereas largescale oil shale development in Colorado and Utah could conceivably provide 10 percent or more of the nation's current oil demand for many years. The environmental impacts of oil shale are greater than those of geothermal; moreover, the environmental consequences of geothermal development are geographically confined within a few square miles of each plant. In addition to their zoning powers, each Califormia county was required by law to draw up its own procedures for carrying out the California Environmental Quality Act. Neither Colorado nor Utah has passed such legislation, and counties in the two states have little planning experience. Although the federal government owns about 53 percent of
} 
result is that oil shale development is profoundly affected by the very different political cultures of Colorado and Utah; whereas geothermal development in California is more sharply affected by the political, economic, and demographic context of specific counties.

\section{Demography}

In Utah, political, religious, and ethnic diversity are minimal. Environmental issues rarely make the political agenda, and the state has generally supported accelerating oil shale development. By contrast, environmental issues versus development goals have loomed large in Colorado politics as one of the issues dividing the political parties. Democrats in Colorado tend to stress environmental protection and Republicans to promote energy development. How the tradeoffs are made tends to vary with which party controls state politics at any particular time. As a result, the state government's posture toward oil shale development with regard to environmental problems is potentially more volatile in Colorado than in Utah.

In California's geothermal arena, local (rather than state) institutions dominate the regulatory process, and environmental opposition is predominantly local as well. Support for or opposition to geothermal development depends upon the distribution of costs and benefits (which in turn is affected by the local political, economic, and demographic context); and the prevailing outlook varies from one local political jurisdiction to another, even from one county to its nearest neighbor.

\section{Existing Institutions}

Under the California Environmental Quality Act of 1970, the counties are the lead agency responsible for environmental impact statements. ${ }^{2}$ Hence, California environmentalists have access to the decisionmaking process at the local level as well as standing before the courts. Under the law, they can assert that an environmental report is inadequate and thereby delay project continuance until adequate information is supplied. Colorado environmentalists, who are largely based in Denver rather than in the counties where the resource is located, lack such standing before county agencies. Although Colorado environmentalists have enjoyed some access and infiuence with the Lamm administration, their legal standing before both state and county agencies does not approach that available to California environmentalists under CEQA. Consequently, they have concentrated on influencing oil shale development through actions at the federal level-protests to federal agencies and suits filed under federal laws including NEPA. Utah environmentalists are few, isolated, and scattered; they also have little standing before local or state institutions and depend upon the Denver and national groups to defend their interests.

\footnotetext{
the KGRAs in California (750,000 acres), most of the development to date has been on private land. By contrast, the federal government owns about 80 percent of oil shale lands, including the richest deposits. In the future, concern over development of federal geothermal lands may exacerbate state-federal relations in California. But it is unlikely to approach the intensity of such concern in the Rocky Mountains because the amount of land in question is substantially smaller.

Technically, the county is the lead agency during the exploration and development phase; for plant certification, the State Energy Commission will soon take over lead agency status. However, once enough wells have been developed to support a power plant, it is highly unlikely that the facility would be denied certification. The crucial decisions supporting or inhibiting geothermal development occur during exploration and development when county agencies dominate the regulatory process.
} 


\section{Past and Present Interactions}

In both Colorado and The Geysers area of California, conflict among environmentalists, governmental bodies, and developers has a history of several years. In contrast, developers in the Imperial Valley face a fairly clean slate unencumbered by past conflicts. In Colorado, the hostility engendered by neglect of environmental interests has been exacerbated by lack of communication between conservationists and energy developers; at The Geysers, the costs of adversary proceedings (delays in development schedules and investment of time, money, and energy) have provided incentives for both sides to seek cooperative solutions. The Geysers case suggests that past rancor can be alleviated if attempts at accommodation are not delayed excessively; the oil shale case suggests that meetings between the principal opposing interests might help overcome the present impasse. In the Imperial Valley, developers have both the opportunity and the burden of constructing fruitful relationships with governmental and private interests.

Precisely how each of these factors affects energy/environment tradeoffs varies with the specific resource, site, actors, and institutions that play a role in development. Consequently, efforts to find reasonable tradeoffs are constrained by the need to understand the local context. Without that understanding, efforts to identify the issues and parties involved, to ascertain the options for bargaining, and to find ways of implementing resolutions are not likely to succeed.

\section{SOURCES OF OPPOSITION}

- Conflicts generally emerge and are resolved in concrete, as opposed to abstract, cases. It is not until specific project (or program) decisions must be made or environmental impacts assessed that the parties will join the conflict.

In California, opposition to geothermal development has typically emerged only after leasing or drilling plans have been announced; at The Geysers, opposition did not emerge until after environmental consequences had been experienced. Opposition to oil shale gained momentum once DOI announced its plans to lease oil shale lands in Colorado and Utah. The earlier and stronger emergence of oil shale conflicts reflects the larger scale of oil shale plans compared with geothermal plans as well as the similarities between oil shale and coal development. Environmentalists understand that developing only one or two oil shale plants would not be economic, ${ }^{3}$ whereas a single geothermal plant of $110 \mathrm{Mw}(\mathrm{e})$ is. Moreover, environmentalists concerned with shale development can use their knowledge of the effects of coal mining to visualize oil shale effects, but one cannot generalize easily from geothermal steam to hot brine development. Therefore, the environmental threat of oil shale development is perceived as more ominous and prominent than that posed by geothermal.

The reactive nature of environmental politics extends beyond our oil shale and geothermal examples. Initially, opponents of nuclear, coal, and oil development also fought specific projects targeted for specific sites. Even nuclear power, the target

\footnotetext{
${ }^{3}$ Because of economies of scale in refining and transportation and recoupment of R\&D and "first-of-akind" plant costs.
} 
of numerous protests and lawsuits, has successfully weathered broad attempts to ban or limit siting on a state-wide basis. It is difficult to build and maintain broad coalitions either for or against a specific energy source. But when development becomes associated with a specific location, the interested parties can identify their likely supporters and tailor their arguments to concrete interests. The implication is that balancing energy and environmental goals at the level of national policy is unlikely to forestall opposition when those policies are carried out in specific locations.

- Conflicts over energy development may be rooted in substantive or procedural issues (whether the costs outweigh the benefits and how both are distributed versus who should have access to the decisionmaking process). Misinformation about the project's goals, impacts, or decisionmaking further confound the resolution process.

In both the oil shale and geothermal cases, substantive conflicts have been exacerbated by procedural disputes-e.g., environmentalists' demands for access to the decisionmaking process and subsequent irritation at not being heard. In oil shale, conservationists became inflamed over what they perceived as their deliberate isolation from the decisionmaking process and intensified their opposition to the federal government's leasing and commercialization programs. At The Geysers, environmentalists' frustration over their exclusion from utility and regulatory decisionmaking spurred them to seek redress through the courts. In both cases, but most intensely for oil shale, inconsistencies led to misunderstandings about the goals or agenda of key decisionmakers and heated the conflicts further. For example, the credibility of environmental protection afforded under the Prototype Leasing Program was seriously damaged by a DOI study in 1974 calling for immediate large-scale deployment of an oil shale industry. The fact that the study was a contingency planning effort and not DOI policy was not communicated to environmentalists. Thus communication among all parties (which also implies some access to the decisionmaking process) is an important ingredient to the successful resolution of environmental conflicts.

- Reducing uncertainty about the environmental consequences of energy development may stimulate opposition in the short run, but it is necessary to long-run resolution.

Opposition to geothermal steam development did not emerge until after people knew what the environmental consequences were. Opposition to oil shale development has been fueled by information about the environmental and social consequences of coal mining in western towns. Clearly, uncertainty about the environmental impacts of development complicates both parties' assessments of the costs and benefits of development. It may contribute to undue intransigence based upon overly pessimistic judgments or foster inattention to problems that later emerge as serious obstacles to development.

Although more information may increase opposition to energy development, earlier knowledge about potential impacts is better than late. To the extent that problems can be anticipated and resolved before a technology becomes commercial, 
unnecessary and expensive delays in plant deployment and production or costly. retrofits may be reduced. The nuclear experience illustrates the cost of failing to obtain adequate safety research data during the early period of commercialization; the case of geothermal development in the Imperial Valley may provide an example of future savings attributable to foresighted efforts to reduce environmental uncertainties through research and planning.

- Difficulties in resolving environmental conflicts are not directly related to the relative levels of environmental damage expected between sites or energy resources; they depend instead on the perceived seriousness of impacts in the specific locality.

Although geothermal steam plants are less environmentally damaging than many other sources of electricity, they have nonetheless stirred considcrable opposition. In Lake County, the surrounding area has recreational and tourist value that appears endangered by geothermal development, and for many residents the scenic beauty and quiet of the area is highly valued as an integral part of their chosen life style. The residents of Lake County do not compare the environmental impacts of geothermal with those of coal or oil shale; rather they compare its environmental consequences with the consequences of no development. Similarly, opponents of specific oil shale or nuclear power plants rarely compare them with alternative energy sources: They focus on the immediate threat and leave such comparisons to government planners. Hence comparing the relative damage associated with different energy sources will not help federal policymakers judge the potential for local resistance to a specific program or project.

- The development of opposition to energy projects can be anticipated by assessing who is likely to be hurt and who is likely to benefit from the project. Such predictions require considerable knowledge of and sensitivity to local cultures and political processes.

We can understand the pro-development posture of Sonoma County as well as the conflicts over geothermal in adjacent Lake by analyzing the incidence of costs and benefits from development. This requires an understanding of the local economy, demography, and values. For example, the residents of both counties benefit indirectly from increased geothermal tax revenues. The difference is that no one in Sonoma, but several groups in Lake (retired people, those who make a living from tourism, and those who place high value on the recreational and scenic value of the area) may suffer as well. Similarly, farmers in the Imperial Valley can be expected to oppose geothermal if their livelihood and agricultural life style become threatened by geothermally induced problems (subsidence, seismicity, crop damage, or insufficient or polluted water). One can also predict that farmers in the oil shale counties of Garfield and Rio Blanco would oppose development if it threatened their life style (through higher prices for water or uncontrolled boom town effects).

Knowing who stands to lose what provides some guidelines for reaching acceptable compromises. However, negotiating such compromises rests on more than information alone. Factors that contribute to successful conflict resolution are discussed below. 


\section{PROCESSES OF ENVIRONMENTAL CONFLICT RESOLUTION}

- Failure to deal with environmental conflict when it first emerges will push the resolution of these issues into adversary arenas. This is not desirable because cooperative resolutions appear to be more effective and long lasting and ultimately less costly than protracted conflict.

It is a common observation that when a strike or lock-out occurs in labor disputes, both sides often end up worse off than if a compromise solution had been found. Although it is not possible to avoid all strikes, it is possible to avert negotiation breakdowns resulting from neglect, misinformation, or inadequate bargaining institutions.

Environmental conflicts are analogous situations. Indifference to environmental concerns has increased the use of adversary tactics (such as court suits, public denunciations, and interventions in regulatory processes) by opponents of both oil shale and geothermal development. Conservationists as well as Colorado's state government believed both DOI and ERDA willfully isolated them from the decisionmaking process with regard to the Prototype Leasing Program and the 1975 Synthetic Fuels Commercialization Demonstration Program. Consequently, they increased their lobbying efforts against federal programs and publicly denounced federal indifference to their concerns. Oil shale environmental groups ultimately filed a suit against DOI for its actions in the Prototype Program.

At The Geysers, utility and regulatory indifference to concerns about the environmental effects of geothermal development led to the development of a citizen organization opposed to insensitive development, spurred environmentalists to seek redress through the courts, and enhanced citizen support for such delaying tactics. Similar problems have plagued the siting and operation of nuclear power plants; in addition, the exclusion of environmentalists and land use planning advocates from legislative and administrative decisionmaking has often led to use of adversary means of access."

In contrast to oil shale, where conflicts over development remain at an impasse, progress has been made toward accommodating environmental and energy goals at The Geysers and Imperial Valley geothermal sites. The four counties making up The Geysers KGRA (Sonoma, Lake, Mendocino, and Napa) have formed a commission to assess the known data on environmental impacts, define unresolved issues, and develop plans for controlled development. Imperial County has developed a geothermal element for its General Plan, affirmed its commitment to preserving the county's basic agricultural economy while stimulating the development of geothermal energy, and taken steps to continue certain aspects of the environmental baseline monitoring conducted by Lawrence Livermore Laboratory. This progress occurred within a cooperative, rather than an adversary, context. Although it is too soon to predict final outcomes, the accommodation in the Imperial Valley may provide the necessary information base and communication network to resolve any conflicts arising later. At The Geysers, the new spirit of cooperation appears to have replaced the earlier pattern of court suits, decisions, and reemergence of the conflict in another arena.

\footnotetext{
- See Rolph (1977) for examples of court suits inspired by the reluctance of the nuclear industry (or the AEC) to accommodate environmental concerns. For an account of how environmentalists have been excluded from Congressional and executive policymaking and then turned to court actions and electoral campaigning, see Enloe (1975).
} 
We know of no definitive study conclusively establishing the superior efficiency of cooperative versus adversary means of conflict resolution; nevertheless, there is an impressive body of literature supporting the proposition. The sense of "ownership" that emerges out of cooperative decisionmaking has been repeatedly cited as a prime factor in effective change (Baldridge, 1975; Bentzen, 1974, Berman, McLaughlin et al., 1977; Chin and Benne, 1969; Gross, Giaguinta, and Bernstein, 1971; and Jones, 1969). In addition, numerous laboratory and field experiments have noted the positive effects of participation on acceptance of decision outcomes (Roethlisberger and Dickson, 1939; Coch and French, 1965; Verba, 1961).

- The cost of adversary processes provides incentives to resolve conflict through cooperative problem solving.

Adversary proceedings or attempts to fight regulatory controls inipose costs on all parties to the conflict. They may delay development schedules and result in reduced profits to developers and fewer tax revenues to the locality. They also necessitate the expenditure of time, money, and energy by all parties. These costs create incentives for both sides to seek cooperative solutions to the conflict. Two cases at The Geysers illustrate this proposition.

After years of indifference to Lake County's complaints about pollution spillovers, Sonoma County (in the form of its Air Pollution Control District) responded by making PG\&E's permit to construct unit 12 conditional on abatement of emissions from several existing plants. PG\&E has therefore stepped up its retrofitting schedule and is currently testing a new abatement process. In Lake County, citizen frustration at official indifference to environmental concerns led to protracted and volatile public hearings and at least three court suits challenging the adequacy of environmental reports. But the escalating costs of conflict have brought both environmentalists and local officials together in an effort to develop a plan for controlled geothermal development. These efforts, initiated by Lake County alone, have expanded to include all four counties in The Geysers KGRA, with Sonoma designated as the lead local government for the new commission.

The emergence of environmental mediators, as well as attempts at direct negotiation between industry and environmental representatives, also attests to the incentives for cooperation arising out of adversary processes. In the 1970s, we witnessed the growth of a new service-environmental mediation. The services performed by mediation groups vary from bringing the contending parties into the same room to formal arbitration; such groups have successfully resolved disputes in several states (Business Week, 1976). Similarly, year long meetings between conservationists and coal industry spokesmen have produced concessions on both sides as well as mutual trust and respect between the two groups (Alexander, 1978; Forbes Magazine, 1977). These developments are largely attributable to each party's belief that the costs of adversary procedures would outweigh the benefits.

With the notable exception of the Colony consortium's work with environmental groups from 1972 to 1974 , the costs of adversary processes do not appear to have stimulated cooperation in oil shale development. In part, this situation is attributable to the doubts of both industry and environmentalists about the potential for oil shale commercialization. Neither side has much incentive to work out environmental problems when one believes the oil shale industry may not soon materialize and the other believes that economic or environmental costs could prevent its 
maturation. In addition, DOI's role in keeping the two groups apart has dissipated whatever potential for cooperation did exist.

Clearly, the costs of protracted conflict are only one of several incentives that affect the willingness of the parties to seek compromise resolutions. If, for example, the costs of ameliorating environmental impacts are very high, developers have less incentive to compromise. If the environmental costs are very high even with extensive mitigation, the environmentalists' incentive to compromise is reduced. But where there is some room for compromise, the expected costs of adversary processes may be crucial in starting the negotiating process.

- Factors that improve the climate for conflict resolution include (1) incentives to negotiate, (2) face to face communication, and (3) participation of all parties to the conflict in the decisionmaking process. Factors that inhibit conflict resolution include the absence of the above plus a lack of congruence between where environmental opponents live and where the energy project or program is located.

Earlier we defined successful conflict resolution as providing some satisfaction to all the parties concerned-e.g., a resolution based on compromise and negotiation rather than the imposition of one side's will over the other. ${ }^{5}$ The factors listed above apply to this definition. The incentives condition is satisfied when mutual gains from cooperation exist and each party recognizes them; no one believes that they can prevail over the other parties or that resolving the conflict is irrelevant. ${ }^{6}$ The ability of each party to impose costs on its opponents-to prevent them from fully obtaining their objectives - enhances incentives to negotiate. Face to face communication increases the potential for reducing suspicion, clarifying misperceptions, and defining areas of agreement and disagreement; the lack of communication inhibits their realization. ${ }^{7}$ Including all parties in the decisionmaking process increases the likelihood of their accepting the outcome, whereas exclusion of one or more parties increases the probability that they will raise the issue again, probably in an adversarial forum.

At The Geysers, all three conditions are present in varying degrees. Under CEQA, environmentalists have been able to file suits that delay development, thereby raising the costs of ignoring their concerns. Through the new four county commission and the work sponsored by the State Energy Commission and DOE, most of the actors concerned with promoting development and protecting the environment have met and had an opportunity to participate in defining issues and future plans. If these processes continue, the prognosis for successful conflict resolution is favorable.

Serious conflicts have not emerged in the Imperial Valley, where county officials and the general public favor geothermal development as long as it remains compatible with the agricultural economy. At present; all parties believe they will gain from cooperation. In addition, the efforts of county officials and Lawrence Livermore Laboratory to further communications among developers and public

\footnotetext{
- Conflicts can also be resolved if one side simply prevails over the other; more often than not, however, such resolutions embitter the loser, leading to reemergence of the conflict in another arena or form.

- See Kelley and Thibaut (1969) for a similar statement of this proposition.

${ }^{7}$ See Allport (1954), Pettigrew (1975) and Wilner (1969) for evidence on the positive relationship between meetings and reduced suspicion.
} 
officials have provided a basis for resolving problems that may arise in the future.

The prognosis for resolving oil shale conflicts is less favorable. Doubts that oil shale will become commercial in the near term have diminished the industry's incentives to negotiate and encouraged environmentalists to believe that they can kill the Prototype Leasing Program. Communication between the two groups has been hampered by DOI's paramount position as decisionmaker. Exclusion of environmentalists and the state of Colorado from key leasing and subsidy program decisions by DOI and ERDA has further exacerbated existing hostilities and added procedural complaints to the substantive ones. Finally, the fact that conservationists are located in Denver-several hundred miles from the actual development area-decreases their legitimacy in the eyes of industry, limits their access to political institutions in the oil shale counties, and diminishes their stake in the potential economic growth benefits of development.

All of these factors inhibit successful conflict resolution. Nevertheless, not all of them are immutable. Clear signs that oil shale is or is not economic would alter both sides' perceptions of the gains from cooperation; an effort by DOI or the Department of Energy to bring the two sides together could achieve benefits in the form of decreased distrust, opportunities to define and clarify issues, and a greater sense of participation in decisionmaking.

- The regulatory and political processes surrounding the resolution of environmental conflicts vary widely from one area to another. This diversity, coupled with the fluid nature of environmental politics, indicates that one can expect continuing change in the nature of those processes.

The types of issues that arise, the groups articulating those issues, and the processes by which they are reflected in regulatory or political arenas vary for different resources and locations. Even in the adjacent counties of Sonoma and Lake, geothermal developers have faced sharply different regulatory processes and outcomes. Similarly, Rio Blanco County in Colorado has thus far successfully asserted jurisdictional and permission rights over federal lands within its boundaries while Garfield County (also in western Colorado) has not. Differences betwen state laws and practices add to this diversity: California passed its own version of NEPA in 1970; neither Utah nor Colorado has followed suit.

The regulatory environment is not stable over time. Changes in federal, state, and county legislation and practices continue to be made, the passage of a California bill limiting the review period for environmental impact reports, for example. Even if laws and regulations were stable, change is inevitable. New actors and issues arise over time; old actors may change their viewpoints, strategies, or influence as one issue recedes and another arises.

This variability complicates the task of those who seek to promote energy development. Not only must they understand regulations and actual practice at three governmental levels, they must also adapt to a constantly changing context. Moreover, if they wish to be involved in more than one jurisdiction, they must learn to work with different actors and adjust to different legal and practical constraints in each locality. For these reasons, developing relevant information and contacts is a significant part of the costs of energy development. For any long-term activity, creating and maintaining a strong capability for communication with local and state actors is a prerequisite for successful development. 


\section{CONCLUSION}

Environmental politics tend to be reactive and heavily influenced by economic, cultural, and political factors. These factors shape what people value as well as the process by which they convert those concerns into issues and go about resolving them. As the factors that shape values change, so do the issues, the actors, and the processes of conflict emergence and resolution. This is generally true across the United States and throughout the world. ${ }^{8}$ The realities of environmental politics mean that efforts to resolve conflicts between energy and environmental goals cannot follow simple formulas but must be adapted to a dynamic and varied political context.

Although we emphasize the need to adapt such efforts to differences across time and space, our analysis does not lead to the conclusion that a central agency has no realistic leverage or options. We have identified common features of an effective conflict resolution process that transcend the local differences in issues, actors, and processes. The section that follows builds upon these features to suggest workable alternatives for federal action to resolve conflicts.

- Enloe's (1975) comparative analysis of pollution politics in the United States, Japan, Britain, and the Soviet Union underlines the importance of cultural differences in determining the values placed on environmental protection and the effects of different political structures on issue mobilization and resolution. 


\section{IMPLICATIONS FOR DOE AND ITS FIELD OFFICES}

In this section we discuss the implications of our research for federal involvement in resolving environmental issues and the criteria by which federal agencies might choose to intervene. Although the data base is limited, the basic context of environmental conflict resolution identified here-dominance of local (as opposed to national) interests, regulatory and political variability across space and time, change in environmental concerns and tactics-appears typical of energy project implementation throughout the nation. Moreover the factors we have identified as contributing to successful conflict resolution transcend the variability in context across space and time. For these reasons, the following policy implications should have significance beyond the immediate examples of geothermal and oil shale development.

\section{THE ROLE OF ENVIRONMENTAL R\&D}

Before addressing the federal role in the resolution of environmental conflicts, we discuss the relationship between environmental disputes and DOE's major role in environmental research. There are two major categories of enviranmental research: (1) basic research on the potential effects of a new technology or process, regardless of where it may be deployed; and (2) assessments of the environmental impacts of a specific project or program. Reducing uncertainties about the environmental consequences of either the technologies in general or specific projects can lay the groundwork for accommodation of conflicting interests. It can also provide new grounds for environmental opposition.

Nevertheless, the fact that new research might increase opposition to development should not discourage DOE from undertaking it. Earlier knowledge about environmental impacts and risks may actually facilitate commercialization in the long run. Incomplete information on the health effects of sulfur dioxide led to more severe $\mathrm{SO}_{2}$ standards and, therefore, greater constraints on coal-fired power plants than appear justifiable given later research. In the nuclear case, the AEC's early inattention to the fuel cycle and lack of sound test data on which to base its safety standards may have contributed to later backfitting delays and higher deployment costs, as well as declining public confidence in the decisionmaking process (Rolph, 1977).

This study has not addressed basic research on the environmental impacts of energy technologies because such work is usually not directly tied to site specific implementation. ' But our analysis does have implications for assessing the environmental impacts of specific projects. In particular, we have found that both the expected impacts and people's perceptions of them vary from one location to another. Given this variation, environmental analyses should be adapted to the problems associated with specific sites and should address the problem in terms under-

\footnotetext{
Nevertheless, such inputs are crucial to the setting of priorities among alternative energy sources and technologies and ultimately affect specific project decisions as well.
} 
stood by local actors. The environmental research agenda should reflect potential implementation problems as well as a set of generic issues identified by environmental scientists. And the results should be disseminated to the local actors in a timely and useful manner; to the extent possible, information should be made available during the course of the research and local actors should be brought into the process of interpreting the implications of the analysis for future development.

DOE's environmental work in both the Imperial Valley and The Geysers area of California provide helpful examples of such adaptation. In the Imperial Valley, where geothermal development is in its infancy, Lawrence Livermore Lab prepared a comprehensive analysis of existing environmental conditions against which future changes caused by geothermal operations can be measured. At The Geysers, where several geothermal steam plants are already operating, LLL assessed existing environmental data and identified questions for which sufficient data have not yet been compiled. In both areas, DOE and LLL have responded to local concerns about the effects of development (e.g., they have sought out local views on what the environmental problems are and adapted the research agenda accordingly), have disseminated findings before project completion, and have taken care to communicate the results in a form that nonscientists can understand and to involve local actors in discussions of their implications.

\section{RESOLVING ENVIRONMENTAL CONFLICTS}

The federal role in resolving environmental conflicts associated with energy project implementation is limited. For most energy projects, the beneficiaries and losers are geographically circumscribed and lack a national perspective. Arguments about national priorities, particularly when set in the context of asking Area A to incur environmental costs so that Area B can enjoy the energy benefits, are simply not persuasive to these actors. ${ }^{2}$

The structure of the federal system is such that state and local approval is necessary for most energy projects. At both levels of government, concern over federal encroachment on historical rights is considerable. As we have seen, county governments have taken steps to assert their authority over energy development on federal lands within their boundaries; both county and state regulators have often avoided enforcing federal environmental standards or, conversely, promulgated standards with even more stringent requirements. In the absence of greater consensus on the nature of the energy problem and how to solve it, state and local resistance to unilateral federal initiatives is not likely to recede.

When the chips are down, the federal government has limited power to tell independent state or local governments what to do or to enforce "agreements" that one or more parties have not accepted..$^{3}$ Even if it is legally empowered to make decisions that favor one or the other's side, it cannot easily stop other governments from using their powers to subvert or modify federal actions. Nor can it stop private or public groups from filing court suits to avoid complying with unwelcome edicts.

\footnotetext{
2 If the environmental costs can in some manner be compensated for, then Area A residents may agree. In the absence of such "side-payments" (which are often difficult to arrange), national interest arguments are not likely to carry much weight.

s See Sundquist (1969) and Derthick (1970) for similar views on the federal government's limited ability to influence the actions of other governments.
} 
Consequently, the federal government should seldom play a directive role in environmental conflict resolution. By directive, we mean trying to impose a resolution or to administer the dispute (consulting the parties separately and then unilaterally suggesting or deciding the outcome). Rather, the federal government's role should be facilitative-in the sense of improving communications, bringing the parties together, and clarifying uncertainties or misunderstandings.

As we noted in Section IV, it is possible to anticipate opposition to specific energy projects or programs by asking who is likely to be hurt and who is likely to benefit from the project. This suggests that undertaking prophylactic measures before a project gets underway and before the potentially opposing parties have entered into conflict may accomplish two objectives: (1) reducing the probability of conflict emergence and (2) enhancing the probability of successful resolution if conflict does begin. Although this research has not evaluated the effectiveness of anticipatory action, it does point toward some steps that may be useful.

Certainly the guidelines for environmental impact assessments suggested above fall in this category: (1) adapting the analysis to the specific site by seeking out local views on what the environmental problems are, (2) incorporating those views into the research agenda, (3) disseminating the results in a timely manner, and (4) including local actors in discussions of the implications' of those results for future development. Similar principles should be applied to the planning and operation of pilot facilities and demonstration plants.

Playing a facilitative role, either before or after conflict has emerged, requires (1) sensitivity to the local context (knowing who the actors are, ascertaining their concerns and priorities, and understanding how local institutions work); (2) flexibility and adaptability to changing circumstances and actors; (3) a belief, together with supporting actions, that at least some of the problems are local (not national) in scope and should therefore be resolved at that level; and (4) even-handedness in dealing with the various parties (potential or actual) to a dispute.

\section{Examples of Successful and Unsuccessful Federal Action}

The Imperial Valley Environmental Project and the later stages of DOE's environmental work at The Geysers illustrate the application of these principles. The IVEP was successful because of efforts to understand local priorities and to adapt the research and data transfer plans to the concerns of the relevant actors in the valley (farmers, developers, county and state officials). In the process, the project managers demonstrated good faith-a belief that local concerns were important and actions that supported that belief without giving undue attention to any particular interest.

At The Geysers, DOE managers adapted their agenda and methods to the special concerns and considerably more volatile context of the four counties. Because geothermal power was already on-line in one of the four counties, providing baseline data against which to measure future effects was neither feasible nor desirable. Instead, LLL held joint workshops with the GRIPS Commission to identify issues of concern and gaps in the existing data base whose closure would facilitate the planning and implementation of controlled development. This effort required a delicate sensitivity to the diverse positions of county officials, developers, and environmental advocates in the four counties. 
The Prototype Leasing Program for oil shale illustrates the lack of these principles. The Department of Interior failed to provide for regular communication among all parties until 1974 when the Oil Shale Environmental Advisory Panel was formed. By then, many of the most important program decisions affecting the environment had been made and conservationists' fears that DOI was industry's handmaiden had been exacerbated by earlier events. Among them were the exclusion of conservationists from the panels that prepared the draft EIS, the short review period before EIS hearings, and DOI's decision to let industry nominate tracts for leasing. Although OSEAP helped DOI define the most important environmental issues, its effectiveness as a communication forum was limited. Industry was not formally represented on the panel (although their representatives attended meetings); conservationists had only two members.

In trying to administer the leasing program, DOI also tried to administer the conflict resolution process. Department officials frequently met with conservationists, public officials, and industry representatives sequentially and then proposed their own solutions. As a consequence, DOI actually kept the contending parties apart rather than bringing them together.

We do not know whether a different approach might have resolved the oil shale impasse. Nor can we say that the IVEP and Geysers examples provide overriding proof of the superiority of facilitative versus directive styles of conflict resolution. Perhaps the success of the Imperial Valley Project can be attributed to the lack of real conflict over geothermal development in that area. However, the counter example is The Geysers, where DOE has managed to work with contending groups and overcome initial fears that the federal government would seek to control local destinies. Perhaps the problems of the Prototype Leasing Program reflect the very real differences in scale and impact of oil shale versus geothermal development. But the Colony oil shale case illustrates that progress can be made when environmentalists and industry meet together; the National Coal Project illustrates the potential for accommodating diverse interests associated with another large and environmentally damaging resource.

These examples suggest that facilitative strategies work. Our findings about the specific, diverse, and ever-changing nature of conflict resolution processes emphasize the importance of sensitivity to the local context and adaptability to change for working out reasonable tradeoffs between energy and environmental goals. Those that point out the negative results of indifference to local concerns and the degree to which procedural disputes inhibit accommodation of conflicting interests underline the importance of accepting local concerns as legitimate and being evenhanded in negotiations with the contending parties.

\section{Options for Involvement}

The tools for playing a facilitative role include each of the options depicted below.

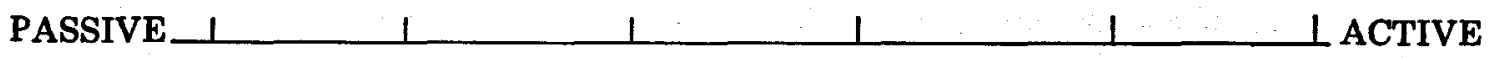

$\begin{array}{cccccc}\text { No } & \text { Disseminating } & \text { Providing } & \text { Facilitating } & \text { Conducting } & \text { Mediating } \\ \text { Role } & \text { Information } & \text { Funds } & \begin{array}{c}\text { Coaperative } \\ \text { Endeavors }\end{array} & \text { Studies } & \text { Disputes }\end{array}$


We defined each of these options in Section I; here we clarify their organizational prerequisites.

As one moves from left to right along the continuum, the need for a local presence increases; the tax on federal resources and organizational capacity grows; and the political component of the federal role becomes more important (in the sense that the need for coordinating, facilitating, and persuading becomes more critical).

Disseminating information to those involved in site-related environmental issues requires sufficient knowledge of the local context to identify appropriate audiences and their capacity for understanding technical information. Knowing what and whom to fund or how to promote cooperation among several public or private organizations requires considerably more "on the ground" contact than does providing information. Conducting environmental studies or environmentally related projects on the site of an energy project necessitates a continuing organizational presence in the area, and mediating disputes requires intimate knowledge of the positions and characteristics of the parties involved and skills in negotiation. An ever present danger in attempting to mediate a dispute is that one may become a party to it instead. We have no examples of ERDA or DOE acting as a mediator among our cases and would caution the Department of Energy against playing such a role unless all parties request its participation and the requisite organizational skills are present.

In some cases, the federal government may be a party to an environmental dispute. This is most likely to occur when it leases land for development, or funds or conducts pilot, demonstration, or commercialization programs. In such cases, federal choices are severely constrained but still include some flexibility in terms of disseminating information, funding or conducting environmental studies, and facilitating cooperation. Furthermore, the options for involvement are not necessarily mutually exclusive: In the course of a pilot or demonstration project, the federal government can facilitate cooperative arrangements among developers, governmental bodies, and environmental groups. In addition, it can conduct its own research to meet NEPA impact statement requirements and can also incorporate local concerns into the study through expanding the research agenda or funding additional work desired by local parties. The good will that can accrue from allowing local participants greater control over the process may more than make up for any loss due to some overlapping of effort.

\section{Criteria for Choosing Among Federal Options}

The criteria for selecting a role for DOE in environmental disputes suggested below apply whether or not DOE is currently involved. Obviously, however, prior federal involvement may condition whether or not the criteria for involvement are met. Factors that should guide federal decisions about whether and how to become involved in attempting to aid the resolution of environmental conflicts include: (1) the attitudes of the local parties toward federal involvement, (2) the adequacy of existing resources and institutional processes for generating information or resolving conflicts, and (3) the federal agency's organizational capacity to render assistance. These factors point to the following questions and decision rules, to be considered sequentially:

- Is a federal presence desired by the local parties? 
When key local parties oppose the federal agency's presence or assistance, efforts to resolve environmental conflicts (by providing funds, conducting studies, facilitating cooperative endeavors or mediating disputes) are not likely to succeed. Before taking on an activist role, the agency should establish credibility with the local parties-state and local government agencies, environmental groups, and developers. This requirement also applies when federal involvement is limited to reducing uncertainties about the environmental impacts of a specific project. Even when the agency is required by law to carry out its own environmental assessment work, it should establish contacts with the relevant local parties and adapt the research to their concerns and priorities.

- Can the local parties resolve environmental uncertainties without federal assistance?

If local resources and expertise are adequate to carry out the planning and analysis necessary to reduce environmental uncertainties, no federal involvement in funding studies is indicated. If resources are inadequate, but expertise is available, then the federal government may consider funding the necessary studies through the local parties. Local people often prefer this route because it gives them control over the money and increases the chances that the money will be used in ways they feel are most important. For several reasons, federal agencies are understandably reluctant to do this: Local actors may not use the money in a way they deem proper to their goals or the national interest, federal agencies often have a clear and understandable interest in using their own personnel, and selection of whom and what to fund is a real problem for all federal agencies. Nevertheless, only when the local parties have neither the resources nor the ability to obtain the requisite expertise should the federal government step in to conduct an environmental study or project.

- Can the local parties resolve environmental conflicts without federal assistance?

If existing processes for allowing access and settling disputes are functioning well, there is probably little that federal action could accomplish. In addition, injecting a federal agency into local processes can bring a host of legal and administrative requirements (additional impact statements, new accounting procedures, hiring guidelines, and reporting requirements) that can materially offset any advantages the agency might offer. The effect may be to reduce the local parties' flexibility by an amount greater than the value of the federal agency's contribution.

If existing processes are inadequate, or if they produce a succession of adversarial joustings, the federal agency might consider ways to bring the contending parties together. The federal role should be to encourage direct communication among the contending parties and to ratify acceptable agreements rather than to advocate or impose solutions. Meetings can take place in many arenas-working groups or advisory committees that help prepare program guidelines or environmental impact statements; symposia or workshops on problems of development, environmental impacts, or regulation; efforts to put together the funds and expertise for specific projects. They can be sponsored by a federal agency, state or local governments, developers, or environmental groups. Decisions about what the 
forum is or who sponsors it should be adapted to specific circumstances. In some cases DOE may be able to point out to the conflicting parties what the costs of failing to compromise may be, citing cases of protracted disputes. However, when the federal agency itself is sponsoring a specific development effort, the NEPA process provides a timely mechanism for establishing local relationships early in the project.

- Does the federal government have the organizational resources to undertake the task?

To conduct on-site projects or studies or to facilitate cooperation among contending interests requires a substantial political; as well as technical, presence that is sometimes unavailable to federal agencies. Neither DOE's laboratories nor headquarters staff can substitute for an informed and effective regional office. When such support is not available, DOE should seriously reconsider the advisability of site-related undertakings.

\section{Organizational Implications for DOE}

Many of the criteria suggested above require a knowledge of the local context that is not always available to federal agencies. Even when the federal government is only indirectly involved in site-specific project implementation, it still requires some "on the ground" contact. For example, decisions to fund environmental assessments or planning studies require prior assessments of the following questions: (1) Is the study or project needed? (2) Would it be done without federal funding? (3) Who is best equipped to carry it out? Each judgment requires substantial knowledge of the local setting, knowledge that the Washington staff cannot easily obtain.

Judgments about attitudes toward federal initiatives in conducting studies or the capacity of local institutions and processes to effectively resolve environmental issues require even greater sensitivity to local practices and perceptions. No handbook on intergovernmental relations can substitute for the experience gained by personnel who know the relevant actors as well as how the institutions work in practice.

These conclusions have several implications for DOE operations:

- The federal presence cannot emanate from headquarters because national offices cannot credibly reflect local or regional interests.

- All parties must be assured access to the federal agency. In particular, access should not depend upon the ability to finance trips to Washington.

- To provide a credible understanding of local conditions, the federal presence should be continuing.

DOE's field offices are the logical resource for developing a continuing and credible local presence. Headquarters staff are hampered by their physical distance from local sites and by the sheer impossibility of becoming an expert on multiple areas. The labs are basically research organizations and are generally not equipped to develop and maintain the local contacts required for assessing numerous project proposals, much less local capacities, practices, and attitudes toward DOE. Individual laboratories may be able to implement a particular local project in combination 
with an effective field office, but that needs to be clearly distinguished from assuming a wide variety of political tasks in a region:

To develop local contacts, experience, and expertise, field offices need to be appropriately staffed and strategically located. They also require sufficient authority to function as more independent arms of the federal agency. Although this study has not focused on the desirable attributes of field offices, it does provide implications for those organizational qualities conducive to the successful operation of projects under field direction. They are the features that made the Imperial Valley Environmental Project work:

- Clear authority and legitimacy at each organizational node;

- Promotion and support of field direction at headquarters, including the delegation of decisionmaking authority and credible field control over financial resources; and

- Clear lines of communication between headquarters and the field.

Together with sensitivity to the local context and participation by local interests, these characteristics constitute the features associated with successful project implementation throughout the federal government." The creation of DOE provides an opportunity for a thorough evaluation of how the field offices can help implement the department's mandate to increase energy supplies in an environmentally acceptable manner.

- For example, a major study of 293 innovative educational projects sponsored by the federal government identified the following key components of effective implementation: staff training keyed to the local setting; participation by teachers in materials development; support from the superintendent, district officials, and principals; and flexible and adaptive planning coupled with frequent and regular staff communication. Similarly, an analysis of 24 federal demonstration projects concluded that successful diffusion was facilitated by on-site management, local participation in project planning and operations, and the absence of tight time constraints; but they were hindered by headquarters pressure for unrealistic goals (a constraint often associated with heavy federal funding). See Berman and McLaughlin (1977) and Baer, Johnson, and Merrow (1976). 


\section{BIBLIOGRAPHY}

Alexander, Tom, "Promising Try at Environmental Detente for Coal," Fortune, February 13, 1978, pp. 94-102.

Allport, G. W., The Nature of Prejudice, Addison-Wesley, Reading, Massachusetts, 1954.

Anderson, Stephen O., "Environmental Impacts of Geothermal Resource Development on Commercial Agriculture: A Case Study of Land Use Conflict," in Lawrence Berkeley Laboratory, Proceedings of Second United Nations Symposium on the Development and Use of Geothermal Resources, San Francisco, California, May 20-29 1975, Vol. 2, Washington, D.C., 1976, p. 1318.

Anspaugh, L. R., and P. L. Phelps, An Overview of the Imperial Valley Environmental Project, Lawrence Livermore Laboratory, Livermore, California, 1976a.

_. Imperial Valley Environmental Project: Progress Report, Lawrence Livermore Laboratory, Livermore, California, October 1976b.

Area Oil Shale Office, Federal Prototype Oil Shale Program, Geological Survey, Department of Interior, Grand Junction, Colorado, June 13, 1977.

Ashland Oil, Incorporated, and Occidental Oil Shale, Incorporated, Oil Shale Tract C-B: Modifications to Detailed Development Plan, p. III-43.

Axtmann, R. C., "Emission Control of Gas Effluents from Geothermal Power Plants," Environmental Letters, Vol. 8, 1975, p. 136.

Bacon, C. F., et al., Engineering Geology of The Geysers Geothermal Resources Area, Lake, Mendocino and Sonoma Counties, California, State of California Resources Agency, Department of Conservation, Division of Mines and Geology, Special Report No. 122, Sacramento, 1976.

Baer, W. S., L. L. Johnson, and E. W. Merrow, Analysis of Federally Funded Demonstration Projects, The Rand Corporation, R-1926-DOC, April 1976.

Baldridge, J. Victor, "Organizational Change and the Consultant's Role: Rules for Effective Action," in J. Victor Baldridge and Terrence E. Deal (eds.), Managing Change in Educational Organizations, McCutchan Publishing Co., Berkeley, California, 1975, pp. 283-298.

Bentzen, Mary M., Changing Schools: The Magic Feather Principle, I/D/E/A Reports on Schooling, McGraw-Hill, 1974.

Berman, P., M. W. McLaughlin, et al., Federal Programs Supporting Educational Change, The Rand Corporation, R-1589-HEW, 7 Vols., 1974-1977.

Chin, Robert, and Kenneth D. Benne, "General Strategies for Effecting Changes in Human Systems," in Warren G. Beggis, Kenneth D. Benne, and Robert Chin (eds.), The Planning of Change, Holt, Rinehart, and Winston, Inc., New York, 1969 , pp. 32-59.

Coch, Lester, and John R. P. French, Jr., "Overcoming Resistance to Change," in Harold Proshansky and Bernard Seidenberg, Basic Studies in Social Psychology, Holt, Rinehart, and Winston, Inc., New York, 1965.

Colony Development Operation, Oil Shale, A Symposium for Environmental Leaders: The Colony Case Study, Atlantic Richfield Company, 1974.

Comptroller General, Review of the 1974 Project Independence Evaluation System, OPA-76-20, April 21, 1976. 
Cook, C. A., "Operation Breakthrough," in W. S. Baer et al., Analysis of Federally Funded Demonstration Projects: Supporting Case Studies, The Rand Corporation, R-1927-DOC, April 1976.

Council on Environmental Quality, Fourth Annual Report, September 1973, p. 370.

Derthick, Martha, The Influence of Federal Grants, Harvard University Press, Cambridge, Massachusetts, 1970.

Duscha, J., "Bonanza in Colorado: Who Gets It?" The Atlantic Monthly, March 1966, p. 82.

Ellickson, Phyllis L., with Saundra Brewer and Kathleen Knight, Balancing Energy and the Environment: The Case of Geothermal Development, The Rand Corporation, R-2274-DOE, June 1978.

Energy Daily, August 17, 1977.

Energy Data Requirements of the Federal Government, hearings before the subcommittee on activities of regulatory agencies of the Permanent Select Committee on Small Business, House of Representatives, 93rd Cong., Washington, D.C., January 28, 1974.

"Energy Future: Can You Fight Progress?" The Atlantic, Vol. 241, No. 4, April 1978.

Enloe, Cynthia H., The Politics of Pollution in a Comparative Perspective, McKay, New York, 1975.

The Environmental Defense Fund, Incorporated, Colorado Open Space Council, Incorporated, Friends of the Earth, Incorporated, and Denver Audubon Society, Incorporated, versus Thomas S. Kleppe, in his official capacity as Secretary of the U.S. Department of the Interior, and Peter A. Rutledge, in his official capacity as Area Oil Shale Supervisor; a civil action filed December 1976, in the U.S. District Court for the District of Columbia.

Environmental Impact Assessment Project, A Scientific and Policy Review of the Final Environmental Impact Statement for the Prototype Oil Shale Leasing Program of the Department of the Interior, Institute of Ecology, Washington, D.C., October 29, 1973.

Energy Research and Development Administration, The National Energy Plan, ERDA 76-1, 1976.

"ERDA Laboratories: Los Alamos Attracts Some Special Attention," Science, Vol. 196, May 13, 1977.

Ermak, Donald L., "A Scenario for Geothermal Electric Power Development in Imperial Valley," The International Journal, Vol. 3, No. 2, April 1978, pp. 203-217.

Fluor Engineers and Constructors, Inc., Oil Shale Processing Technology, Report SFT 102, Los Angeles.

Forbes Magazine, "Getting to Know Each Other," August 7, 1977. p. 62.

Freeman, J. E., J. P. Kottensteete, and P. M. Gatsees, Information and Data Flows in Societal Problem Areas, Focus: Energy, Denver Research Institute, Colorado, May 1977, p. 26.

Freudenberg, W. R., "The Social Impact of Energy Boom Development on Rural Communities: A Review of the Literature and Some Predictions"; paper presented at the annual meeting of the American Sociological Society, August 1976. 
Fullen, Michael, "Overview of the Innovative Process and the User," Interchange, Vol. 3, Nos. 2-3, 1972, pp. 1-46.

Gilmore, J. S., "Boom Towns May Hinder Energy Resource Development," Science, Vol. 191.

Goldsmith, Martin, Engineering Aspects of Geothermal Development in the Imperial Valley, Environmental Quality Laboratory, California Institute of Technology, Memorandum No. 20, Pasadena, December 1976.

Gordon, Richard L., "The Hobbling of Coal: Policy and Regulatory Uncertainties," Science, Vol. 200, April 14, 1978, pp. 153-158.

Green, Harold P., "Safety Determinations in Nuclear Power Licensing," Notre Dame Lawyer, Vol. 43, June 1968.

—_, "Nuclear Safety and the Public Interest," Nuclear News, Vol. 15(9), No. 75, 1972.

—, "Nuclear Power: Risk, Liability and Indemnity," Michigan Law Review, January 1973, pp. 479-510.

Gross, N., J. B. Giaquinta, and M. Bernstein, Implementing Organizational Innovations, Basic Books, Inc., New York, 1971.

Grossman, A. P., "Economic Evaluation of Combined In Situ and Surface Retorting of Oil Shale," paper presented at the Tenth Oil Shale Symposium, Golden, Colorado, April 1977.

Harmston, G., "Utah's Attitude Toward Development of Oil Shale," Quarterly of the Colorado School of Mines, Vol. 70, No. 4, October 1974.

Imperial County Department of Public Works, Draft-Geothermal Element, Junè 1977.

Interagency Oil Shale Task Force, Potential Future Role of Shale Oil: Prospects and Constraints, Department of Interior, 1974.

Jet Propulsion Laboratory, Report on the Status of Development of Geothermal Energy Resources in California, prepared for CERCDC, Document No. 5040 25, Pasadena, 1976.

Johnson, L. L., "Personal Rapid Transit System," in W. S. Baer, L. L. Johnson, and E. W. Merrow, Analysis of Federally Funded Demonstration Projects: Case Studies, The Rand Corporation, R-1927-DOC, April 1976.

Joint Legislative Committee on Energy Policy, Energy Policy Report, Utah, January 1977.

Jones, Garth N., Planned Organizational Change, A Study in Change Dynamics, Routledge, Kegan Paul, London, 1969.

Kelly, Robert E., "Predicting the Effect of Geothermal Emissions on the Temperature and Relative Humidity in the Imperial Valley of California," Geothermal Energy, Vol. 5, No. 1, 1977, pp. 18-22.

Kelley, Harold H., and John W. Thibaut, "Group Problem Solving," in Gardner Lindzey and Elliot Aronson (eds.), The Handbook of Social Psychology, Addison-Wesley, Menlo Park.

Kirkham, W. G., and S. J. Brown, State and Local Permit Study: An Analysis of Administrative Factors Affecting Geothermal Development at The Geysers, Governor's Office of Planning and Research, Sacramento, California, 1976, pp. 4-5c.

Lake County Air Pollution Control Board, New Source Review Rules, 1976.

Layton, David W., Water Supply Dilemmas of Geothermal Development in the 
Imperial Valley of California, Lawrence Livermore Laboratory, Livermore, California, 1976.

Lindsey, M. K., and P. Supton, Geothermal Energy: Legal Problems of Resource Development Stanford Environmental Law Society, Stanford, 1975, pp. 122144.

Massachusetts Institute of Technology, The FEA Project Independence Report: An Analytical Review and Evaluation, PB244741, Cambridge, May 1975.

Matthew, Paul, Geothermal Operating Experience, Geyser Power Plants, Pacific Gas and Electric Co., San Francisco, 1975.

"Mediation Studies as Way to Resolve Environmental Disputes," Washington Post, January 13, 1978, p. A7.

Merrow, E. W., Constraints on the Commercialization of Oil Shale, The Rand Corporation, R-2293-DOE, September 1978.

Miller, Norman, "Environmental Impact of Coal, Shale Mining is Issue in Far West," The Wall Street Journal, Vol. 184, No. 82, October 24, 1974.

Mint, M., "Oil Shale Tract Vastly Undervalued," Washington Post, March 3, 1974.

National Coal Policy Project, Where We Agree, Draft Report Sponsored by the Center for Strategy and International Studies, Georgetown University, Washington, D.C., February 9, 1978.

"National Environmental Policy Act of 1969," Laws of 91st Congress-1st Session, January 1, 1970, Section 101 (C).

Pasqualetti, M.J., Geothermal Impact in the Imperial Valley: Analyses and Recommendations Based on Analogous Experiences, University of California at Riverside, 1976.

Perry, R., et al., Development and Commercialization of the Light Water Reactor, 1946-1976, The Rand Corporation, R-2180-NSF, June 1977.

Pettigrew, T. F. (ed.), Racial Discrimination in the United States, Harper and Row, New York, 1975.

Pimentel, K. D., Unpublished water quality data, Imperial Valley Environmental Project, Lawrence Livermore Laboratory, Livermore, California, 1976.

Pressman, Jeffrey, and Aaron Wildavsky, Implementation, University of California Press, Berkeley, 1973.

Project Independence Task Force Report on Oil Shale, Washington, D.C., 1974, p. 169.

Prouty, D., "She Digs for Facts in Oil Shale," Denver Post, December 23, 1973.

"Questions of Survival: Public Hearings on Project Independence," Newsweek, August $26,1974$.

"Removing the Raricor from Tough Disputes," Business Week, August 30, 1976, pp. 50-51.

Rio Blanco Oil Shale Project, Detailed Development Plan and Revised Detailed Development Plan, submitted to ARCO Oil Shale Supervisor, Department of Interior.

- Social and Economic Impact Statement Tract C-a, Gulf Oil Corporation and Standard Oil Company (Indiana), 1976.

Roethlisberger, F. J., and W. J. Dickson, Management and the Worker, Harvard University Press, Cambridge, 1939.

Rolph, E., Regulation of Nuclear Power: The Case of the Light Water Reactor, The Rand Corporation, R-2104-NSF, June 1977. 
Ross, C., "State Damage Feared. Rivals Ask Vanderhoof for Block on Oil Shale," Denver Post, July 19, 1974, p. 45.

Schuller, C. R., et al., Legal Institutional and Political Problems in Producing Electric Power from Geothermal Resources in California, Battelle Human Affairs Research Centers, Seattle, 1976, p. 239.

Seudekm, N. R., "Environmental Impacts on Energy Markets and Conservation Planning," paper prepared for NSF-MITRE Workshop on Long Run Energy Demands, McLean, Virginia, June 1976.

Sherman, H., "Colorado Policy in Oil Shale Development," Quarterly of The Colorado School of Mines, Vol. 70, No. 4, October 1977.

Shinn, J. H., et al., Exposures of Field-Grown Lettuce to Geothermal Air PollutionPhotosynthetic and Stomatal Responses, Lawrence Livermore Laboratory, Livermore, California, 1976.

Steek, J. H., "NEPA After Five Years: A Second Look," paper prepared for delivery at the annual meeting of the Society for the Study of Social Problems, San Francisco, August 1975.

Sundquist, James L., Making Federalism Work, The Brookings Institution, Washington, D.C., 1969.

Tolmasoff, M., Report on $\mathrm{H}_{2} \mathrm{~S}$ Air Quality and The Geysers' Geothermal Development, Northern Sonoma County Air Pollution Control District, 1976, mimeo.

U.S. Department of the Interior, Final Environmental Statement for the Geothermal Leasing Program, 6 vols., Washington, D.C., 1973.

Verba, Sidney, Small Groups and Political Behavior, Princeton University Press, 1961.

Vollintine, L., and O. Weres, Public Opinion in Cobb Valley Concerning Geothermal Development in Lake County, California, Lawrence Berkeley Laboratory, LBL-4447, Berkeley, March 1976a.

-, Public Opinion in Cobb Valley Concerning Geothermal Development in Lake County, California, Lawrence Berkeley Laboratory, LBL-5204, Berkeley, June 1976b.

Welles, C., The Elusive Bonanza, E. P. Dalton and Company, Incoporated, New York, 1970, pp. 131-132.

White River Shale Project, Detailed Development Plan, submitted to Area Oil Shale Supervisor, Department of Interior.

Wichelman, A. F., "Administrative Agency Implementation of the National Environmental Policy Act of 1969: A Conceptual Framework for Explaining Differential Response," Natural Resources Journal, Vol. 16, April 1976.

Wilner, D. M., et al, Human Relations in Interracial Housing: A Study of the Contact Hypothesis, Russell, 1969.

Wilson, G. C., "U.S. Acting to Give Oil Shale to Utah," Washington Post, December 13, 1973, p. A6. 